"This is the peer reviewed version of the following article: [Accounting and Finance, 2021] which has been published in final form at [https://onlinelibrary.wiley.com/doi/10.1111/acfi.12738] purposes in accordance with Wiley Terms and Conditions for Self-Archiving." 


\section{ACCOUNTING \& FINANCE afaanz}

\section{The Effect of Board of Directors' Expertise and Tax Avoidance on Corporate Debt}

\begin{tabular}{|r|l|}
\hline Journal: & Accounting and Finance \\
\hline Manuscript ID & ACFI-2020-430.R1 \\
\hline Weywords: $:$ & $\begin{array}{l}\text { Corporate governance, Board of directors, Financial expertise, Tax } \\
\text { avoidance, Corporate debt }\end{array}$ \\
\hline Abstract: & $\begin{array}{l}\text { We find that there is no association between financially expert outside } \\
\text { directors on the board and corporate debt. However, we do find a } \\
\text { positive association between the proportion of financially expert inside } \\
\text { directors on the board and debt. We also find that the debt-substitution } \\
\text { effect is significantly intensified by the presence of outside directors on } \\
\text { the board with financial expertise, which suggests that the advice offered } \\
\text { by these directors better informs managers to make decisions about the } \\
\text { trade-off between the benefits and costs of debt and non-debt tax } \\
\text { shields. We find no such effect for inside directors. }\end{array}$ \\
\hline
\end{tabular}

\section{SCHOLARONE ${ }^{\mathrm{m}}$ \\ Manuscripts}




\title{
The Effect of Board of Directors' Expertise and Tax Avoidance on Corporate Debt
}

\begin{abstract}
This study examines the effect of board of directors' expertise and tax avoidance on corporate debt. We find that there is no association between financially expert outside directors on the board and corporate debt which is contrary to some prior research findings (e.g., Booth and Deli, 1999; Guner et al., 2008). However, we do find a positive association between the proportion of financially expert inside directors on the board and debt. We also find that the debt-substitution effect is significantly intensified by the presence of outside directors on the board with financial expertise, which suggests that the advice offered by these directors better informs managers to make decisions about the trade-off between the benefits and costs of debt and non-debt tax shields. We find no such effect for inside directors. Overall, this study extends the literature on corporate governance, tax avoidance and corporate debt.
\end{abstract}

Key words: Corporate governance; Board of directors; Financial expertise; Tax avoidance; Corporate debt

JEL Classification: G32; G34; H26.

\section{Introduction}

Seminal research by Fama (1980) and Fama and Jensen (1983) has emphasized the importance of having both inside executives (management) and outside members (non-management) on the board of directors. The presence of outside directors on the board has been shown to be an effective mechanism for monitoring and advising managers (e.g., Beasley, 1996; Lanis and Richardson, 2011). Therefore, having independent corporate boards to monitor and advise managers assists a firm's decision-making process (e.g., Dahya and McConnell, 2005; Dalton et al., 1998; Gillan and Starks, 1998). The literature has also suggested that the impact of the board on financing policies is further improved by directors with financial expertise, but research also exists suggesting otherwise (e.g., Guner et al., 2008). Although the literature has provided mixed evidence about financially expert outside directors' impact on financing policies (e.g., Booth and Deli, 1999; Kroszner and Strahan, 2001; Adams et al., 2018; Drobetz et al., 2018), no prior research has examined the effect of inside directors' financial expertise on corporate debt policy.

Booth and Deli (1999) argued that the financial expertise of outside directors has a positive effect on corporate debt levels generally, but not unequivocally. While Kroszner and Strahan 
(2001) provided mixed results about the impact of outside directors banking expertise on the financing alternatives of investment decisions, research by Ajinkya et al. (2005), Lim (2011) and Richardson et al. (2014) reported a link between corporate debt and tax avoidance ${ }^{1}$ (the debt-substitution effect) and/or corporate governance (outside directors and institutional ownership). Concerning inside directors, the literature is limited to suggesting that these directors desire lower levels of debt in a firm's capital structure (mitigated by their incentive structures) with no reference to their financial expertise (e.g., Firth, 1995; Friend and Hasbrouck, 1988; Friend and Lang, 1988). We combine and extend both streams of literature to examine the important research question about the effect of financial expertise of both outside and inside directors on corporate debt policy in terms of the debt-substitution effect.

Bhojraj and Sengupta (2003) investigated the impact of board of director composition and institutional investors on bond ratings and yields. They found that a higher proportion of outside directors on the board and greater institutional ownership improved bond ratings, lowers yields and thus encourages higher debt utilisation. Based on this research, Lim (2011) argued that better corporate governance in terms of institutional ownership magnified the debt-substitution effect. ${ }^{2}$ Using a sample of Korean firms, Lim (2011) found empirical support for his argument.

Richardson et al. (2014) examined the impact of tax avoidance on corporate debt (the debtsubstitution effect) and the effect of outside directors on both debt and the debt-substitution effect. They reported a negative association between debt and tax avoidance, and a negative association between the proportion of outside directors on the board and debt. Finally, they found that outside directors magnify the debt-substitution effect.

Firth (1995) suggested that managers prefer moderate or low levels of debt, as it is in their self-interest to reduce the chances of corporate bankruptcy, so they will influence senior

\footnotetext{
${ }^{1}$ Corporate tax avoidance is defined broadly as the downward management of taxable income through tax-planning activities (Hanlon and Heitzman, 2010). Our definition covers legal (and quasi-legal) and illegal activities.

2 Specifically, better firm monitoring through greater institutional ownership decreased the opportunities for managerial opportunism and rent diversion, which is associated with tax avoidance, and lowers the cost of debt.
} 
executives to make conservative business decisions and follow prudent financing policies. Conversely, Stulz (1988) argued that executives favor more debt in a firm's capital structure, so that they own a larger portion of it.

Kroszner and Strahan (2001) examined the trade-offs between the benefits from bank monitoring and the costs of active bank involvement in firm management to explain which nonfinancial firms in the U.S. have representatives from commercial banks on their boards. They found that bankers tend to be on the boards of firms in which shareholder-creditor conflicts are less likely to be important, and where firms are larger, less volatile and have more tangible assets. Booth and Deli (1999) explored the role of financial executives on boards of nonfinancial firms. They reported that the presence of commercial bankers on boards is positively associated with short-term, long-term and total bank debt. More recently, Drobetz et al. (2018) found that more experienced outside directors are valued at a premium compared to firms with less experienced outside directors.

Guner et al. (2008) investigated how financial expertise of outside directors affects firms' investment and financing decisions and focus on the presence of commercial and investment bankers on the board. They found that while the presence of unaffiliated commercial bankers on the board is positively associated with bank borrowing, the presence of affiliated commercial bankers is not significant, suggesting that although commercial bankers supply expertise to firms, they do not sit on boards to primarily monitor lending. However, to the best of our knowledge, the effect of inside director financial expertise on debt and the debt-substitution effect is untested empirically.

We extend prior research by Richardson et al. (2014) by applying the theory advanced by Booth and Deli (1999), Kroszner and Strahan (2001) and Guner et al. (2008) to empirically examine whether the financial expertise of outside directors on the board impacts the debtsubstitution effect. We analyze the impact of financial expertise of outside directors on debt as 
prior research shows that outside directors with financial expertise affect firm policies beyond more accurate disclosure and better audit committee performance (e.g., Guner et al., 2008). ${ }^{3}$ We conjecture that outside directors with greater financial expertise are in a better position to advise managers about a firm's optimal capital structure as determined by the trade-off between the benefits and costs of debt. Further, to the best of our knowledge, no prior research has empirically analyzed the effect of financial expertise of inside directors on corporate debt policy. Although, the incentives and motivations of inside directors differ from those of outside directors, their financial expertise impacts on many facets of the firm, so we also empirically test for the first time the conjecture that greater financial expertise of inside directors may improve the decision-making process of a firm's optimal capital structure.

Based on sample of up to 3264 firm-year observations over the 2000 to 2013 period, we find that there is generally no association between financially expert outside directors on the board and corporate debt which is conflicts with prior research findings (e.g., Booth and Deli, 1999; Guner et al., 2008). However, we do find a positive association between the proportion of financially expert inside directors and debt. We also find that the debt-substitution effect is significantly magnified by the presence of outside directors on the board with financial expertise, which suggests that the advice given by these directors better informs managers to make decisions about the trade-off between the benefits and costs of debt, and non-debt tax shields. We observe no such effect for inside directors.

This study makes several contributions to the literature. First, it reports evidence showing that there is no association between financially expert outside directors and total debt, which runs contrary to prior research. However, we do provide evidence for the first time that an association exists for inside directors and debt levels. Second, this study shows that firms with financially expert outside directors on their boards strengthen the debt-substitution effect, but

\footnotetext{
${ }^{3}$ Outside directors provide financial expertise when sitting on corporate boards to senior executives in terms of all matters financial (Finkelstein and Ann, 2003; Adams and Ferreira, 2007).
} 
that inside financially expert directors have no impact thereon. Thus, this study does help to resolve the question about the effect of financially expert boards on corporate debt policy and the debt-substitution effect. Third, this study is also the first to report that financially expert inside and outside directors, by their knowledge and advice, enable optimal capital structure decisions to be made in a firm with respect to debt and the debt-substitution effect, respectively. We hope that our results concerning inside directors leads to further research into the impact of inside directors' financial expertise. Finally, this study's findings should be of interest to several capital market participants, including analysts, financial institutions and investors regarding analyzing corporate debt and the related substitution effect.

The rest of the paper is organized as follows. Section 2 describes the background literature and develops hypotheses. Section 3 outlines the research method, and Section 4 reports the empirical results. Section 5 conducts additional analyses, and Section 6 concludes.

\section{Background literature and hypotheses development}

\subsection{Financial expertise of directors and corporate debt}

Exploring the general impact of outside directors on total level of debt, Richardson et al. (2014) found that outside directors had a negative impact on total debt levels, where a higher proportion of outside directors on the board was associated with lower levels of debt. This finding is explained by one of two competing theories posited by Richardson et al. (2014) where managers: (1) choose a restrictive capital structure (i.e., lower debt levels) to bond themselves; and (2) form a reputation with the capital markets in the absence of other management monitoring mechanisms (i.e., fewer outside directors) (Hartford et al., 2008). Richardson et al. (2014) implicitly rejected the alternative explanation which suggests that lower debt levels are a due to better board monitoring because of a higher proportion of outside directors represented on the board (Friend and Lang, 1988). However, prior studies exploring the influence of financial expertise of outside directors on corporate debt found the opposite result. Booth and 
Deli (1999) found that the presence of commercial bankers on the board of directors is positively associated with short-term, long-term and aggregate bank debt, so it is the presence of unaffiliated commercial bankers on the board that is positively associated with bank borrowing, while the presence of affiliated commercial bankers is not. Thus, it is challenging to suggest that bankers on boards arrange a greater amount of loans from the banks which employ them to the firms upon whose boards they sit. Booth and Deli (1999, p.230) stated that:

Financial executives may have a comparative advantage in evaluating alternative debt contracts and pricing arrangements. To the extent firms borrow, then, we expect that they can benefit from a financial executive's comparative advantage in evaluating alternative debt contracts and pricing arrangements. If outside directors who are financial executives supply general debt-market expertise i.e., their comparative advantage in debt contract evaluation extends to all types of debt, then we expect that firms that borrow more, regardless of the source, will have outside directors who are financial executive.

The empirical results of Booth and Deli (1999) appear to contradict those of Richardson et al. (2014). However, their claim (from the above quote) appears ambiguous. In particular, if outside directors who are appointed as financial executives (inside directors) to supply debt market expertise, there is an expectation that firms will borrow more (Booth and Deli, 1999). If debt and corporate governance are substitutes, managers monitoring mechanisms and the presence of outside directors with financial expertise may well be insignificant. An alternative explanation for the Booth and Deli (1999) results is that better monitoring by outside directors (with or without financial expertise) encourages managers to increase their level of borrowing. Adams et al. 's (2018) study on outside directors' experience (which is partly informed by expertise) has shown that more experienced outside directors attract a premium. Specifically, Adams et al. (2018) found that having directors with more industry experience and higher firm value is more pronounced for firms with large investment programs, large cash reserves, and during crises. This research provides further evidence of an association between outside director financial expertise and firms' capital structure. 
Guner et al. (2008) response was somewhat mooted about any positive impact of financially expert outside directors on corporate financial policy. While accepting the advisory role of financially expert outside directors, they argued that this role can be problematic, especially if outside directors are affiliated with financial institutions, as there is potential for them to pursue the interests of those institutions rather than shareholders' wealth maximization (Malmendier and Shanthikumar, 2007; Reuter, 2006). Guner et al. (2008) argued that the effect of investment bankers on public debt echoes that of commercial bankers on loans. They argued that investment bankers deal with larger debt issues (particularly if their bank is an underwriter). Thus, a higher debt level is associated with bankers on corporate boards, which is consistent with research by Booth and Deli (1999). Certainly, larger debt issues arise mainly from banks who have board representation, while consistent with Booth and Deli (1999), it is a result of banking directors comparative advantage in evaluating alternative debt contracts and pricing arrangements, and thus advising management to borrow more.

Collectively, the evidence presented above regarding outside directors who are also bankers (and by implication financial experts) suggests a positive association between the financial expertise of outside directors and corporate debt, and specific public debt issues. However, the explanations differ. On one hand, Booth and Deli (1999) found that higher debt levels are associated with unaffiliated bankers on the board, so the reason for the higher debt is attributable to the financial expertise that the outside director's provide to managers. On the other hand, Guner et al. (2008) found that larger public debt issues are associated with affiliated bankers on the board and the reasons are more consistent with maximizing the creditors wealth, being the bank employing the outside director, instead of stockholders' wealth maximization. Finally, Richardson et al. (2014) reported a negative association between outside directors on the board and debt levels, which suggests that this association is explained by managers using corporate governance mechanisms and debt as substitute monitoring mechanisms. 
Overall, the results from prior research are mixed. There appears to be significant tension in the literature surrounding the association between the financial expertise of outside directors and corporate debt. We expect that corporate boards with a greater representation of outside directors who are financial experts will impact debt levels either positively or negatively. We develop the following non-directional hypothesis:

H1a: All else equal, there is an association between the proportion of outside directors on the board with financial expertise and corporate debt.

Presently, there is a lack of research examining the effect of the financial expertise of inside directors on corporate decisions and their impact on debt levels. On the one hand, Firth (1995) found that managers and executives preferred lower levels of debt to reduce the likelihood of bankruptcy. Further, that debt finance frequently constrained managerial actions due to debt covenants that lenders insisted on (e.g., Firth, 1995; Friend and Lang, 1988). Alternatively, Stulz (1988) found that executives may want to own a larger portion of the firm that they managed and one way of achieving this was to finance expansion through corporate debt. Thus, we expect that inside directors (i.e., executives) with financial expertise are even more influential with respect to debt levels of a firm depending on which of the above views is appropriate. We develop the following non-directional hypothesis:

H1b: All else equal, there is an association between the proportion of inside directors on the board with financial expertise and corporate debt.

\subsection{The debt-substitution effect and outside/inside directors}

The concept of the debt-substitution effect can be traced-back to research by Myers (1984) who found that firms are not indifferent about debt or equity financing, as the level of debt depends on the associated benefits and costs. Later research refined this idea by suggesting that the amount of debt is inversely related to non-debt tax shields (e.g., DeAngelo and Masulis 1980; 
MacKie-Mason 1990; Dhaliwal et al. 1992). Later research has since provided evidence in support of that effect (e.g., Graham and Tucker, 2006; Lim, 2011; Richardson et al., 2014).

Fama (1980) and Fama and Jensen (1983) argued that the structure of the board of directors is a key factor in showing that a board can be an effective monitor of firm managers actions, and stressed the value of having both inside (manager) and outside (non-manager) board members. They also argued that the board's value in monitoring managers is a function of the combination of both the insiders and outsiders who serve on the board. The internal managers of the firm are normally the most important members of the board as they hold valuable information about the firm's activities that aids the board in making good decisions (Fama, 1980; Fama and Jensen, 1983). The board is expected to include some of the firm's managers, however, it is unlikely to play an effective role in decision control unless it can limit the discretion that managers have to make decisions in the firm (Beasley, 1996). As managers have a large information advantage due to their full-time status and insider knowledge, the board can easily become their tool, so they ignore shareholder interests (Williamson, 1984). When mangers control the board, this also helps them to collude and expropriate shareholder wealth by carrying out non-profit-maximizing activities (Fama, 1980; Fama and Jensen, 1983). Prior studies show that left unchecked, managers engineer accounting numbers in the annual report to increase their own compensation, which is linked to the financial performance and/or stock price of the firm (e.g., Fama, 1980; DeAngelo et al., 1994; Yermack, 1996).

Fama (1980) argued that the ability of the board to be a market-induced mechanism for the low-cost internal transfer of control can be improved by including outside board members. The added value that outside directors bring can be best appreciated by viewing them as skilled adjudicators whose task is to oversee competition among managers. Boards usually include several outside members who act as mediators in disagreements among managers and sanction decisions that involve agency problems, so selecting a higher proportion of outside directors on 
the board is likely to increase the effective monitoring and advising of managers. Further, compensation payments to outside directors are usually not linked to the financial performance or stock price of the firm, so they have greater incentive to monitor managers (Fama and Jensen, 1983). Finally, outside directors have valuable expertise that can be used to advise managers, so decision-making can be improved in the firm (Fama and Jensen, 1983).

Richardson et al. (2014) argued that a firm's optimal capital structure (as determined by the trade-off between the benefits and costs of debt) presented several challenges and problems for managers. The challenge is to be able to decrease (increase) debt levels as tax avoidance increases (decreases). They argued that outside directors provide valuable advice to managers about the debt-substitution effect to guide them to make optimal financial structure decisions that maximize shareholders' wealth, so the presence of outside directors on the board should improve a manager's ability to effectively evaluate the potential trade-offs between tax benefits and debt costs (the debt-substitution effect). Richardson et al. (2014) found that a higher proportion of outside directors on the board of directors magnified the debt-substitution effect, so outside directors contributed positively as advisors to decisions that impacted a firm's capital structure. However, an important research question that remains unanswered is whether outside directors with distinct attributes and knowledge in the form of financial expertise intensify (weaken) the debt-substitution effect.

The idea that outside directors have a major role as financial experts in advising managers has been highlighted in several early studies (e.g., Mace, 1971; Vance, 1978, Fama and Jensen, 1983; Rosenstein and Wyatt, 1990). Financial expertise of outside directors has also been accepted by senior executives to be relevant in assisting them to make decisions (e.g., Mace, 1971; Vance, 1978). Guner et al. (2008) argued that financially expert outside directors could affect firm policies beyond more accurate disclosure and better audit committee performance rather than merely monitoring, as they spend much of their time advising managers. Thus, it is 
possible that outside directors could provide more financial expertise regarding financing decision activity than others to senior executives when sitting on boards.

The literature has explored the effect of financial expertise of outside directors on financial and investment decisions generally, but has not looked at the debt-substitution effect. Booth and Deli (1999) studied the role of financial executives on the boards of non-financial firms with the intention of analyzing two previously unexamined roles: (1) the supply of expertise; and (2) the monitoring of business relationships. They found that outside directors were generally not affiliated with banks that lend to the boards upon which they sit to avoid conflicts of interest, so this was a sign that firms used outside directors more for their financial expertise to advise managers, instead of only monitoring a bank’s lending relationships.

Kroszner and Strahan (2001) analyzed the role of bankers (as outside directors) on boards. They found that bankers tend to be on the boards of large and stable firms with high tangible asset ratios and less reliance on short-term debt financing. However, they are less clear about the role that bankers play on boards, be it as advisors or monitors. In highly volatile firms, there are not as many bankers, so they are less likely to be on the boards of firms that may benefit most from active monitoring. This could suggest that bankers are mainly on boards to provide their financial expertise and advice.

Guner et al. (2008) explored how finance experts on the board affect corporate policies and whether affiliation impedes their advisory role. They studied firms' investment decisions and found that there are links between the presence of bankers on the board and firms finance and investment policies, but not in a way in which the financial institutions that hire them can benefit. They also showed that bankers serving on boards help to reduce the sensitivity of investment to a firm's cash flows by increasing its access to loans from banks that they are affiliated with. Guner et al. (2008) concluded that board members' impact on corporate policies goes beyond mere monitoring and is affected by director interests that conflict with those of 
shareholders, and that financing, investment and compensation outcomes do not always improve when financial experts join the board. Fich (2005) argued that firms appoint CEOs as outside directors who may possibly provide added financial and management expertise. They found that CEOs from commercial banks are perceived to be more valuable than CEOs from other organizations, which is consistent with the idea that these CEOs as outside directors are sources of unique expertise, industry contacts and business acumen, and are of far greater value than outside directors from other occupations.

The prior research reviewed above shows that financial expertise of outside directors affects corporate policies in general and those specifically related to financial matters. However, whether the advice of outside directors who are de-facto financial experts has a positive (negative) effect on corporate debt policy has seen some tension in the literature. Coupled with evidence that outside directors who act as general advisors to managers magnify the debtsubstitution effect (see Richardson et al., 2014), it is possible that outside directors with financial expertise intensify this effect, so increasing tax avoidance in firms with a greater number of financially expert outside directors on their boards is likely to better inform managers about the trade-off between the benefits (costs) of debt and non-debt tax shields, and lead them to reduce corporate debt levels. We develop the following directional hypothesis:

H2a: All else equal, the negative association between tax avoidance and corporate debt is intensified for firms with outside directors with financial expertise on their boards.

To date, there is a lack of research examining the potential effect of inside directors (and their financial expertise) on corporate decisions, while no research has analyzed their impact on the debt-substitution effect. Therefore, it is not clear whether the financial expertise of inside directors is associated with the debt-substitution effect. Given that there is no theory or prior evidence indicating whether the financial expertise of inside directors impacts the debtsubstitution effect, we develop the following (null) hypothesis: 
H2b: All else equal, the negative association between tax avoidance and corporate debt is not intensified for firms with inside directors with financial expertise on their boards.

\section{Research design}

\subsection{Sample selection}

We initially collected corporate governance data from the Boardex database over the 2000 to 2013 period. ${ }^{4}$ We gathered financial data from the Compustat database. Firms were matched by firm-year using a range of variables, such as ticker and firm ID, ISIN code and CIK code, providing an initial sample of 22,447 firm-year observations. Firms in the financial services and utilities sectors (3,481 firm-year observations) were excluded from our sample as they face different regulations which are likely to affect the calculation of their debt and tax avoidance measures. Missing data were also removed from our sample (8,983 firm-year observations). In addition, Lim (2011) argues that non-December fiscal year-end firms should be excluded from the sample to mitigate potential variations in tax effects, so they were also removed $(3,831$ firm-year observations). Finally, all non-U.S. firms and firms with negative denominators for computing our effective tax rate (ETR) measures were removed (2,888 firm-year observations), leaving our final sample of 3,264 firm-year observations for empirical testing.

Consistent with prior tax avoidance research, ETR proxy measures of tax avoidance (see below) were truncated between zero and one to mitigate the potential influence of large outlier observations unduly affecting our results (e.g., Armstrong et al., 2010). We also winsorized the tax avoidance proxy measure (see below) at the 1st and 99th percentiles as per prior research (e.g., McGuire et al., 2012). ${ }^{5}$ This provided a final (unbalanced) sample to test our hypotheses

\footnotetext{
${ }^{4}$ For instance, the number of directors on the board, qualifications and the total number of other boards (both quoted and private) for each director. Sample observations for this study are chosen over the 2000 to 2013 period as the Boardex database coverage of U.S. firms is limited prior to the 2000 year.

${ }^{5}$ We note that the independent and control variables were also winsorized at the 1st and 99th percentiles in our study, consistent with prior research (e.g., McGuire et al., 2012).
} 
with the following firm-year observations with all data available, being 3,264 for ETR(1yr), 2,750 for $\operatorname{ETR}(3 \mathrm{yr})$ and 1,959 for $\operatorname{ETR}(5 \mathrm{yr})$, respectively.

Table 1 reports the sample distribution based on the 2-digit Global Industry Classification Standard (GICS) codes. Our sample included a higher proportion of firms in the information technology (27.18percent), industrials (20.28percent) and health care (20.16percent) categories. The sample observations appear to be reasonably distributed across all industry categories.

\section{[Insert Table 1 Here]}

\subsection{Dependent variable}

The dependent variable is corporate debt. Consistent with prior research by Rajan and Zingales (1995) and others (e.g., Graham and Tucker, 2006; Byoun, 2008; Richardson et al., 2014), we measure corporate debt (DEBT) in terms of market debt (MDEBT),${ }^{6}$ which is calculated as total debt $(\# \mathrm{dlc}+\# \mathrm{dltt})$ divided by the sum of the market value of equity and total debt (((\#)sho * $\#$ prcc_f $)+\#$ tstkp - \#dvpa $)+(\#$ dlc $+\#$ dltt $))^{7}$

\subsection{Independent variables}

The independent variables are the proportion of outside directors on the board with financial expertise, the proportion of inside directors on the board with financial expertise and corporate tax avoidance.

All education/qualifications of directors are designated with a condition that they are measured as a dummy variable, coded as 1 where there are directors who hold a position on the board during the firm-year that is likely to provide the board with financial expertise

\footnotetext{
${ }^{6}$ We also use book debt (BDEBT) which is measured as total debt (\#dlc + \#dltt) divided by total assets (\#at) (Graham and Tucker, 2006; Byoun, 2008) in our study. Our (untabulated) results are qualitatively similar to those reported in this paper based on MDEBT.

${ }^{7}$ Data items refer to financial statement data taken from the Compustat Database that were sourced from WRDS, and include total current and non-current liabilities (\#dlc + \#dltt), the number of ordinary shares on issue (\#csho) multiplied by the year end share price (\#prcc_f), the book value of treasury stock (\#tstkp) and preferred dividends in arrears (\#dvpa).
} 
(FINANCIAL) about corporate debt and taxation, and 0 otherwise. These numbers are then totalled so that each expertise specification denotes the number of directors holding that expertise. We follow prior research by Guner et al. (2008) by analyzing the individual attributes that directors bring to the board, so FINANCIAL denotes a director with a financial degree (e.g., BCom or MBA) or with professional qualifications that include finance and tax (e.g., CPA). LAW denotes a director with professional legal qualifications as this is likely to include, at least some tax expertise. Finally, OTHER represents a director with other degrees and qualifications or expertise that are not expected to provide specific financial or tax expertise (e.g., arts, maths, medicine and science). Each of these designations are then totalled separately for independent (outside) and inside (inside) directors before being calculated as a fraction of total directors. Finally, for convenience, we prefix each of the above director designations with 'i” for independent directors and " $d$ " for inside (dependent executives) directors, respectively.

We use three proxy measures of tax avoidance (TA) from prior research to ensure that our inferences are robust to alternative TA specifications. First, we use the one-year cash effective tax rate $(\operatorname{ETR}(1 \mathrm{yr}))$ as this is commonly used to proxy for the tax burden placed on a firm where managers directly attempt to minimize cash taxes paid out of cash flow, rather than through tax expenses in the financial statements. It is measured by dividing tax paid (\#txpd) by pre-tax earnings (\#pi) over a one-year period (Dyreng et al., 2008, 2010). Second, we use the threeyear cash effective tax rate (ETR(3yr)) which is measured as tax paid (\#txpd) divided by pretax earnings (\#pi) averaged over a three-year period (Dyreng et al., 2008, 2010). Finally, we use the five-year cash effective tax rate $(\operatorname{ETR}(5 y))$ which is measured as tax paid (\#txpd) divided by pre-tax earnings (\#pi) averaged over a five-year period (Dyreng et al., 2008, 2010). Overall, these proxies directly consider the effect of firms' tax avoidance strategy where there is any settling-up over time (Dyreng et al., 2008, 2010). Finally, in terms of the ETR proxy measures, we subtract from 1 so that a more negative ETR indicates increased TA. 


\subsection{Control variables}

We include several control variables in our ordinary least squares (OLS) regression models based on the corporate debt model of Byoun (2008). Specifically, we include operating income $(\mathrm{OI})$, measured as operating income divided by total assets (\#at) in our regression models as a firm with greater earnings may prefer to operate with a higher/lower degree of leverage (Byoun, 2008). The market-to-book ratio (MB), measured as the market capitalization of outstanding shares (\#prcc $f^{*} \#$ csho) divided by book value of net assets, comprising the book value of ordinary equity adjusted for treasury shares and preferred dividends in arrears $(\# c e q+\# t s t k p$ $\# d v p a$ ) is also included. A higher MB is a sign of more attractive future growth options that firms protect by limiting the amount of debt (Adam and Goyal, 2008). Large firms tend to make more debt disclosures, and have less asset volatility or ability to sell such sufficiently large debt issues that the fixed costs of public borrowing are not prohibitive (Byoun, 2008). Therefore, we include total assets (LnA), which is measured as the log of total assets (Log\#at), to proxy for firm size. Depreciation and amortization (DEP), measured as depreciation and amortization (\#dep) divided by total assets (\#at) is also incorporated in our regression models. Firms with more depreciation expenses have less need for interest deductions related to debt financing (Dhaliwal et al., 1992). Firms with a large amount of fixed assets (FA), measured as fixed assets (\#ppent) divided by total assets (\#at) are also likely to have high depreciation expenses, but as such firms have more tangible assets they also have greater debt capacity (Harris and Raviv, 1991). R\&D expenses (RND), measured as R\&D expenditure (\#xrd) divided by net sales (\#sale), is also included in our regression models. RND is a proxy for future expected ventures and serves as a proxy for non-debt tax shields. Common stock dividends (DIV) is measured as common stock dividends $(\# d v c)$ divided by total assets (\#at), and is entered in our regression models to control for the trade-off between debt and dividends in reducing the agency costs of firms' free cash flows (Fama and French, 2002). Finally, the Altman (1968) Z-score (AZ) is 
also included in our regression models, and measures the ex-ante probability of financial distress. Firms use less debt when the expected cost of financial distress is high (Graham, 1996). All variable definitions are described in Table 2.

\section{[Insert Table 2 Here]}

\subsection{Regression models}

The first OLS regression model examines the association between the percentage of outside directors on the board with financial expertise and corporate debt (H1a), and is estimated as follows:

$$
\text { DEBT }=\alpha_{0}+\beta_{1} \text { TA }_{i t}+\beta_{2-3} \text { EXPERTISE }_{i t}+\beta_{4-11} \text { CONTROLS }_{i t}+\varepsilon_{i t}
$$

where DEBT is the dependent variable and is proxied by MDEBT; TA is measured using the ETR separately for one, three and five year intervals; EXPERTISE is the independent variable for outside directors and is proxied by iFINANCIAL and iLAW $;{ }^{8}$ and CONTROLs denote the control variables (OI, MB, LnA, DEP, FA, RND, DIV and AZ).

The second OLS regression model examines the association between the proportion of inside directors on the board with financial expertise and corporate debt ( $\mathrm{H} 1 \mathrm{~b})$, and is estimated as follows:

$$
\text { DEBT }=\alpha_{0}+\beta_{1} \text { TA }_{i t}+\beta_{2-3} \text { EXPERTISE }_{i t}+\beta_{4-11} \text { CONTROLS }_{i t}+\varepsilon_{i t},
$$

where DEBT is the dependent variable and is proxied by MDEBT; TA is measured using the ETR separately for one, three and five year intervals; EXPERTISE is the independent variable for inside (d) directors with financial expertise and is proxied by dFINANCIAL and dLAW; ${ }^{9}$ and CONTROLs comprise the control variables (OI, MB, LnA, DEP, FA, RND, DIV and AZ).

\footnotetext{
8 iOTHER was dropped from the regression model because of collinearity concerns (Hair et al., 2006).

${ }^{9}$ dOTHER was dropped from the regression model due to collinearity concerns (Hair et al., 2006).
} 
The third OLS regression model examines whether the association between tax avoidance and corporate debt is magnified for firms with outside directors with financial expertise on their boards $(\mathrm{H} 2 \mathrm{a})$, and is estimated as follows:

$$
\begin{aligned}
& \text { DEBT }=\alpha_{0}+\beta_{1} T A_{\mathrm{it}}+T A_{\mathrm{it}} * \beta_{2-3} \text { EXPERTISE }_{\mathrm{it}}+ \\
& \beta_{4-5} \text { EXPERTISE }_{\mathrm{it}}+\quad \beta_{6-13} \text { CONTROLS }_{\mathrm{it}}+\varepsilon_{\mathrm{it}}
\end{aligned}
$$

where EXPERTISE * TA are interaction variables between outside director (i) expertise and TA.

The fourth OLS regression model examines whether the association between tax avoidance and corporate debt is magnified for firms with inside directors with financial expertise on their boards (H2b), and is estimated as follows:

$$
\begin{aligned}
& \text { DEBT }=\propto_{0}+\beta_{1} T A_{\mathrm{it}}+\mathrm{TA}_{\mathrm{it}} * \beta_{2-3} \text { EXPERTISE }_{\mathrm{it}}+ \\
& \beta_{4-5} \text { EXPERTISE }_{\mathrm{it}}+\beta_{6-13} \text { CONTROLS }_{\mathrm{it}}+\varepsilon_{\mathrm{it}},
\end{aligned}
$$

where EXPERTISE * TA are interaction variables between inside (d) director expertise and TA.

\section{Empirical results}

\subsection{Descriptive statistics}

Table 3 reports the descriptive statistics for the variables used in our analyses. The mean (median) of MDEBT is 0.249 (0.230) which is consistent with past research (e.g., Byoun, 2008). Our TA variables show a mean (median) for ETR(1yr) of $0.758(0.770)$, ETR(3yr) of 0.736 (0.752), ETR(5yr) of $0.710(0.735)$ respectively, suggesting that the reported pre-tax accounting income generally remained higher than taxable income for our proxy measures of tax avoidance (Richardson et al., 2015). Directors' financial expertise (iFINANCIAL and dFINANCIAL) is our main variable of interest, with independent directors holding a financial degree (iFINANCIAL) mean (median) of 0.189 (0.167), law qualifications (iLAW) mean (median) of $0.024(0.000)$ and other directors (iOTHER) mean (median) of $0.383(0.400)$ in comparison to inside directors (dFINANCIAL) mean (median) of 0.101 (0.000), dLAW mean (median) of 
$0.016(0.000)$, and dOTHER mean (median) of $0.351(0.273) .{ }^{10}$ The descriptive statistics for the control variables (OI, MB, LnA, DEP, FA, RND, DIV and AZ) are also shown in Table 3.

\section{[Insert Table 3 Here]}

\subsection{Pearson correlation results}

Pearson correlation results are presented in Table 4. We find that the TA variables (ETR(1yr); $\operatorname{ETR}(3 y r)$ and ETR(5yr)) are not significantly associated with MDEBT. We observe that there is a positive association between iFINANCIAL $(p<0.05)$ and MDEBT, as well as a positive association between dFINANCIAL and MDEBT $(p<0.01)$. We report a positive association between iLaw $(p<0.01)$ and dLaw $(p<0.01)$ and MDEBT, while dOther has a significant negative association with MDEBT $(p<0.01)$. For the control variables, we find that $\mathrm{OI}$, MB, LnA, FA, RND and AZ are significantly associated with MDEBT $(p<0.01)$, while DEP is significant $(p<0.05)$ with predicted signs (e.g., Byoun, 2008; Dhaliwal et al., 1992; Fama and French, 2002; Graham, 1996; Harris and Raviv, 1991). However, we observe that the control variable DIV is not significantly associated with MDEBT, while other control variables have non-predicted signs (MB and DEP). Table 4 shows that collinearity between our explanatory variables is generally moderate (Hair et al., 2006). ${ }^{11}$

\section{[Insert Table 4 Here]}

\subsection{OLS regression results}

\subsubsection{H1a-outside directors, financial expertise and corporate debt}

Table 5 (Panel A), reports the regression results for H1a. The coefficient for iFINANCIAL is only marginally significant $(p<0.10)$ on a single occasion for the ETR(3yr) TA model, so H1a has minimal support. Therefore, against our prediction, we find limited evidence that outside

\footnotetext{
${ }^{10}$ In additional tests, we aggregated all the individual characteristics of directors, so that there are only those with financial/taxation expertise and those without. The results (untabulated) are qualitatively similar to those reported throughout our paper.

${ }^{11}$ We also computed variance inflation factors (VIFs) when estimating our regression models to test for signs of multi-collinearity among the explanatory variables. Our results (untabulated) show that no VIFs exceeded five for any of our variables, so multi-collinearity is not a concern in our study (see Hair et al., 2006).
} 
directors who have a background in accounting/law/taxation provide any major influence on corporate debt levels. Interestingly, our result is in contrast to the earlier research findings of Booth and Deli (1999) and Guner et al. (2008), and suggests that outside directors with financial expertise do not play a major role in terms of corporate debt. The coefficients for the TA proxies (ETR(1yr), ETR(3yr) and ETR(5yr) are significantly negatively associated with MDEBT across all regression models ( $p<0.05$ or below), which is consistent with the debt-substitution effect (e.g., Graham and Tucker, 2006; Richardson et al., 2014). Finally, the coefficients for all our control variables (OI, MB, LnA, DEP, FA, RND, DIV and AZ) are significantly associated with MDEBT $(p<0.01$, with RND $p<0.10)$ with predicted signs (where appropriate) in several of our regression models, in line with prior research.

\subsubsection{H1b-inside directors, financial expertise and corporate debt}

The regression results for $\mathrm{H} 1 \mathrm{~b}$ are presented in Table 5 (Panel B). The coefficient for dFINANCIAL is significantly positively associated with MDEBT across all regression models $(p<0.01)$. The coefficient for dLAW is significantly positively associated with MDEBT for the $\operatorname{ETR}(3 \mathrm{yr})$ and ETR5(yr) regression models ( $p<0.01$ or below). H1b is supported by our results in this instance. We provide new evidence that inside directors who have a financial or legal background have a significant (positive) effect on corporate debt levels. This is consistent with the view that they prefer to grow the firm with more debt (see Stulz, 1988). The coefficients for all the TA proxy measures (ETR(1yr), ETR(3yr), ETR(5yr) are significantly negatively associated with MDEBT across all regression models $(p<0.10$ or below). This is again supportive of the debt-substitution effect. The coefficients for the OI, MB, LnA, DEP, FA, RND, DIV and AZ control variables are significantly associated with MDEBT $(p<0.01$ with RND $p<0.10$ ) with predicted signs (where appropriate) in some of our regression models, consistent with past research. 


\section{[Insert Table 5 Here]}

\subsubsection{H2a-tax avoidance, outside directors, financial expertise and corporate debt}

Table 6 (Panel A) presents the regression results for H2a. The coefficients for the interaction terms iFINANCIAL*TA, (ETR(1yr), and ETR(3yr), are significant and negatively associated with MDEBT ( $p<0.01$ or below). H2a is supported by our results. In line with our prediction, we find that increasing tax avoidance in firms with a greater representation of financially expert outside directors on their boards better informs managers of the trade-off between the benefits (costs) of debt and non-debt tax shields, and lead them to reduce their corporate debt levels. The coefficients for the TA proxies (ETR(1yr), ETR(3yr) and $\operatorname{ETR}(5 \mathrm{yr})$ are significantly negatively associated with MDEBT across all regression models ( $p<0.05$ or below), which supports the debt-substitution effect. Table 5 (Panel A) also shows that iFINANCIAL is generally not statistically significant in most of our regression models. The coefficients for some of our control variables (OI, LnA, DEP, FA, RND, DIV and AZ) are significantly associated with MDEBT $(p<0.01)$ with predicted signs (where appropriate) in several of our regression models, consistent with prior studies.

\subsubsection{H2b-tax avoidance, inside directors, financial expertise and corporate debt}

The regression results for $\mathrm{H} 2 \mathrm{~b}$ are shown in Table 6 (Panel B). The coefficients for the interaction terms dFINANCIAL*TA (ETR(1yr), ETR(3yr), ETR(5yr) are not statistically significant across all regression models. $\mathrm{H} 2 \mathrm{~b}$ is not supported by our results. We find no evidence that inside directors intensify the negative association between tax avoidance and corporate debt. Importantly, our results suggest that firms with outside directors that possess greater financial expertise, such as financial and taxation qualifications intensify the negative association between tax avoidance and corporate debt, but this association does not hold for inside directors as evidenced by the significance of the dFINANCIAL measure $(p<0.01)$, 
coupled with the significant dLAW variable on two of three occasions ( $p<0.05$ or below). The coefficients for all the TA proxy measures (ETR(1yr), ETR(3yr), ETR(5yr)) are significantly negatively associated with MDEBT across all regression models ( $p<0.05$ or below), which confirms the debt-substitution effect. The coefficients for the OI, LnA, DEP, FA, RND, DIV and AZ control variables are significantly associated with MDEBT $(p<0.01)$ with predicted signs (where appropriate) in some of our regression models, in agreement with past studies.

\section{[Insert Table 6 Here]}

In summary, our regression results report several important findings. First, there is no association between financially expert outside directors on the board and corporate debt. Second, there is a positive association between the proportion of financially expert inside directors on the board and corporate debt. Third, the debt-substitution effect is significantly intensified by the presence of outside directors on the board with financial expertise. Finally, the debt-substitution effect is not intensified by the presence of inside directors on the board with financial expertise.

\section{Additional analyses}

To consider the robustness of our main empirical results, we carry out additional analyses which considers potential concerns of endogeneity and serial dependence in the tax avoidance and board of director data.

\subsection{Potential endogeneity concerns}

It is possible that are our OLS regression results in Tables 5 and 6 may be subject to endogeneity concerns in the form of reverse causality (e.g., Roberts and Whited, 2013). Therefore, after estimating instrumental variable (IV) two stage least squares (2SLS) regression models, ${ }^{12}$ we

\footnotetext{
${ }^{12}$ As per past tax avoidance research by Hasan et al. (2014), religiosity (RELIG) is used as our IV. Offering some support for the use of RELIG as an IV, Boone et al. (2013) finds that firms headquartered in areas that are more
} 
compute the Hausman specification test (HST) (Hausman, 1978) to consider whether our OLS regression models are significantly affected by endogeneity (e.g., Wooldridge, 2010). A significant test-statistic for the HST suggests endogeneity problems for the OLS regression models (i.e., the explanatory variables are correlated with the error term) in Tables 5 and 6 (Wooldridge, 2010). ${ }^{13}$ Overall, we find that the HSTs are not significant for any of our OLS regression models $(p>0.10)$ (untabulated), so the OLS regression models used in our primary analysis outperform the IVs 2SLS regression models. However, to consider the endogeneity issue in the form of reverse causality more generally in our study, we follow prior research by Hermalin and Weisbach (1991) and Coles et al. (2008) and lag all our explanatory variables by one year ( $\mathrm{t}-1)$. We then re-estimate our regression models for $\mathrm{H} 1(\mathrm{a}$ and $\mathrm{b}$ ) and $\mathrm{H} 2 \mathrm{(a}$ and $\mathrm{b}$ ) for outside and inside directors, respectively. The regression results are reported in Tables 7 and 8 .

Table 7 (Panel A) presents the endogeneity results for H1a. The coefficient for iFINANCIAL is not significant, so H1a has no support. This result is reasonably consistent with the main regression results for H1a in Table 5 (Panel A). The coefficients for the TA proxies (ETR(1yr), ETR(3yr) and ETR(5yr) are significantly negatively associated with MDEBT across all regression models ( $p<0.10$ or below), which is in line with the main results in Table 5 (panel A), and supportive of the debt-substitution effect.

Table 7 (Panel B) shows the endogeneity results for $\mathrm{H} 1 \mathrm{~b}$. The coefficient for dFINANCIAL is significantly positively associated with MDEBT across all regression models $(p<0.01)$. The coefficient for dLAW is also significantly positively associated with MDEBT for all regression models $(p<0.01$ or below). The results are in line with the main regression results (see Table

religious are less likely to avoid taxes. RELIG is measured as the fraction of the population in the county of the firm's headquarters that claims affiliation with an organized religion as reported in surveys of the Association of Religion Data Archives (see Hasan et al., 2014). We find that RELIG is generally significant $(p<0.01)$ in the first-stage IVs 2SLS regression models (untabulated). Finally, we find that some of the second-stage regression results are inconsistent (untabulated) compared to the OLS regression results shown in Tables 5 and 6.

${ }^{13}$ We specifically compare the OLS regression models with the IVs 2SLS regression models based on the HST to consider whether the IVs 2SLS models outperform the OLS models (see Wooldridge, 2010). 
5, Panel B), which again supports H1b. The coefficients of the TA proxy measures (ETR(1yr), ETR(3yr), ETR(5yr) are significantly negatively associated with MDEBT across all regression models ( $p<0.10$ or below), which is in accordance with the main results in Table 5 (panel A), and therefore again supports the debt-substitution effect.

\section{[Insert Table 7 Here]}

Table 8 (Panel A) presents the endogeneity results for H2a. The coefficients for the interaction terms iFINANCIAL*TA, (ETR(1yr), and ETR(3yr), are significant and negatively associated with MDEBT ( $p<0.01$ or below). H2a is again supported by our results. However, the coefficients for the TA proxies (ETR(1yr), ETR(3yr) and ETR(5yr) are not statistically significant, while Table 8 (Panel A) indicates that iFINANCIAL is significant in most of our regression models $(p<0.01)$.

Table 8 (Panel B) reports the endogeneity results for $\mathrm{H} 2 \mathrm{~b}$. as per our main regression results in Table 6 (Panel B), the coefficients for the interaction terms dFINANCIAL*TA (ETR(1yr), $\operatorname{ETR}(3 y r), \operatorname{ETR}(5 y r)$ are not statistically significant across all regression models. Thus, $\mathrm{H} 2 \mathrm{~b}$ is once again not supported by our results. However, the coefficients for the TA proxy measures of $\operatorname{ETR}(3 \mathrm{yr})$ and $\operatorname{ETR}(5 \mathrm{yr})$ are significantly negatively associated with MDEBT $(p<0.10)$, which again confirms the debt-substitution effect.

\section{[Insert Table 8 Here]}

Overall, we find that the endogeneity results for hypotheses $\mathrm{H} 1$ ( $\mathrm{a}$ and $\mathrm{b}$ ) and $\mathrm{H} 2$ ( $\mathrm{a}$ and $\mathrm{b}$ ) for outside and inside directors, are consistent with our main regression results. Hence, we conclude that endogeneity does not represent a major problem in our study.

\subsection{Potential serial dependence concerns}

A further issue with our main regression results in Tables 5 and 6 is the possibility of serial dependence concerns in our data (see Hoi et al., 2013). Specifically, tax avoidance activities 
and board of director composition (outside and inside directors) of the firm could remain stable over time. To mitigate statistical concerns arising from serial dependence of regression errors, we re-estimate our regression models using the Fama and MacBeth (1973) procedure with Newey and West (1987) standard errors. We drop the year dummies from our regression models and estimate the regression models by year. We then test the statistical significance of the average coefficients using a t-test ( $t$-statistics are computed based on time-series standard deviations of the regression coefficients). The regression results are shown in Tables 9 and 10 .

Table 9 (Panel A) presents the serial dependence results for H1a. The coefficient for iFINANCIAL is not significant, so H1a is not supported. This result is consistent with the main regression results for $\mathrm{H} 1 \mathrm{a}$ in Table 5 (Panel A). The coefficients for the TA proxies (ETR(1yr) and ETR(3yr) are significantly negatively associated with MDEBT in the regression models ( $p$ $<0.10$ or below), in accordance with the main results in Table 5 (panel A), and supportive of the debt-substitution effect.

Table 9 (Panel B) reports the serial dependence results for H1b. The coefficient for dFINANCIAL is significantly positively associated with MDEBT in the ETR(5yr) regression model $(p<0.05)$. The coefficient for dLAW is also significantly positively associated with MDEBT in the $\operatorname{ETR}(5 \mathrm{yr})$ regression model $(p<0.05)$. The results are consistent with the main regression results (see Table 5, Panel B), which once more supports H1b. The coefficients of the TA proxy measures for ETR(3yr) is significantly negatively associated with MDEBT in the regression model $(p<0.05)$, which is in accordance with the main results in Table 5 (panel A), and again confirms the debt-substitution effect.

\section{[Insert Table 9 Here]}

Table 10 (Panel A) shows the serial dependence results for H2a. The coefficients for the interaction terms iFINANCIAL*TA, (ETR(1yr), and ETR(3yr), are significant and negatively associated with MDEBT ( $p<0.05$ or below). H2a is supported by our results. The coefficients 
for the TA proxies (ETR(1yr), ETR(3yr) and ETR(5yr) are statistically significant $(p<0.10$ or below), which is consistent with the main results in Table 5 (panel A), and supports the debtsubstitution effect, while Table 8 (Panel A) shows that iFINANCIAL is significant in the $\operatorname{ETR}(1 \mathrm{yr})$ regression model $(p<0.01)$.

Table 10 (Panel B) shows the serial dependence results for $\mathrm{H} 2 \mathrm{~b}$. As per our main regression results in Table 6 (Panel B), the coefficients for the interaction terms dFINANCIAL*TA (ETR(1yr), ETR(3yr), ETR(5yr) are not statistically significant across all regression models, so $\mathrm{H} 2 \mathrm{~b}$ is again not supported by our results. However, the coefficients for the TA proxy measures (ETR(1yr), ETR(3yr) and ETR(5yr)) are significantly negatively associated with MDEBT in all the regression models ( $p<0.05$ or below) and supports the debt-substitution effect.

Overall, we find that the serial dependence results for hypotheses $\mathrm{H} 1$ (a and b) and H2 (a and b) for outside and inside directors are consistent with our main regression results.

\section{[Insert Table 10]}

\section{Conclusion}

This study examines the effect of board of directors' expertise and tax avoidance on corporate debt. Our regression results show that there is no association between financially expert outside directors on the board and debt which is contrary to some prior research findings (e.g., Booth and Deli, 1999; Guner et al., 2008). However, we find that there is an association between the proportion of financially expert inside directors on the board and debt. We also find that the debt-substitution effect is significantly intensified by the presence of outside directors on the board with financial expertise, suggesting that the advice supplied by these directors better informs managers to make decisions about the trade-off between the benefits and costs of debt and non-debt tax shields. However, we find no such effect for inside directors.

This study makes the following contributions. First, it offers evidence showing that there is no association between financially expert outside directors and total debt, which runs contrary 
to prior research. Further, we provide evidence for the first time which shows that an association exists in terms of inside directors and debt levels. Second, this study reports that firms with financially expert outside directors on their boards intensify the debt-substitution effect, but that inside financially expert directors have no impact thereon. Therefore, this study helps to resolve the question about the effect of financially expert boards on corporate debt policy and the debtsubstitution effect. Third, this study is also the first to report that financially expert inside and outside directors, by their knowledge and advice, enable optimal capital structure decisions to be made in the firm regarding debt and the debt-substitution effect, respectively. Finally, this study's findings should be of interest to several capital market participants, such as analysts, financial institutions and investors.

Future research could examine the impact of inside directors' financial expertise on other aspects of firms' capital structure. For example, additional research could be carried out concerning the role of inside directors' financial expertise in influencing dividend policy and tax avoidance. We encourage future research in this emerging area.

\section{References}

Adam, T., Goyal, V.K., 2008. The investment opportunity set and its proxy variables. Journal of Financial Research 31, 41-63.

Adams, R., B., Ferreira, D., 2007. A theory of friendly boards. Journal of Finance 62, 1540-6261.

Adams, R.B., Akyol, A.C., Verwijmeren, P. 2018. Director skill sets. Journal of Financial Economics, 130, 641662.

Agrawal, A., Mandelker, G., N., 1987. Managerial incentives and corporate investment and financing decisions. The Journal of Finance 42, 823-837.

Ajinkya, B., Bhojraj, S., Sengupta, P., 2005. The association between outside directors, institutional investors and the properties of management earnings forecasts. Journal of Accounting Research 43, 343-376.

Altman, E.I., 1968. Financial ratios, discriminat analysis and the prediction of corporate bankruptcy. Journal of Finance 23, 189-209.

Armstrong, C.S., Guay, W.R., Weber, J.P., 2010. The role of information and financial reporting in corporate governance and debt contracting. Journal of Accounting and Economics 50, 179-234.

Beasley, M.S., 1996. An empirical analysis of the relation between the board of director composition and financial statement fraud. The Accounting Review 71, 443-465.

Bhojraj, S., Sengupta, P., 2003. Effect of corporate governance on bond ratings and yields: The role of institutional investors and outside directors. Journal of Business 76, 455-475.

Boone, A.L., Casares Field, L., Karpoff, J.M., Raheja, C.G., 2007. The determinants of corporate board size and composition: An empirical analysis. Journal of Financial Economics 85, 66-101.

Boone, J.P., Khurana, I.K., Raman, K.K., 2013. Religiosity and tax avoidance. Journal of the American Taxation Association 35, 53-84.

Booth, J.R., Deli, D.N., 1999. On executives of financial institutions as outside directors. Journal of Corporate Finance 5, 227-250. 
Byoun, S., 2008. How and when do firms adjust their capital structures toward targets? Journal of Finance 63, 1540-6261.

Chaganti, R., Damanpour, F., 1991. Institutional ownership, capital structure, and firm performance. Strategic Management Journal 12, 479-491.

Chen, S., Chen, X., Cheng, Q., Shevlin, T., 2010. Are family firms more tax aggressive than non-family firms? Journal of Financial Economics 95, 41-61.

Coles, J.L., Daniel, N.D., Naveen, L., 2008. Boards: Does one size fit all? Journal of Financial Economics 87, 329-356.

Dahya, J., McConnell, J.J., 2005. Outside directors and corporate board decisions. Journal of Corporate Finance $11,37-60$.

Dalton, D.R., Daily, C.M., Ellstrand, A.E., Johnson, J.L., 1998. Meta-analytic reviews of board composition, leadership structure, and financial performance. Strategic Management Journal 19, 269-290.

DeAngelo, H., DeAngelo, L., Skinner, D.J., 1994. Accounting choice in troubled companies. Journal of Accounting and Economics 17, 113-143.

DeAngelo, H., Masulis, R.W., 1980. Optimal capital structure under corporate and personal taxation. Journal of Financial Economics 8, 3-29.

Dhaliwal, D., Trezevant, R., Wang, S., 1992. Taxes, investment-related tax shields and capital structure. Journal of the American Taxation Association 14, 1-21.

Drobetz, W., Von Meyerinck, F., Oesch, D., Schmid, M.,2018. Industry expert directors, Journal of Banking and Finance 92, 195-215.

Dyreng, S.D., Hanlon, M., Maydew, E.L., 2008. Long-run corporate tax avoidance. The Accounting Review 83, 61-82.

Dyreng, S.D., Hanlon, M., Maydew, E.L., 2010. The effects of executives on corporate tax avoidance. The Accounting Review 85, 1163-1189.

Fama, E.F., 1980. Agency Problems and the theory of the firm. Journal of Political Economy 88, 288-307.

Fama, E.F., French, K.R., 2002. Testing trade-off and pecking order predictions about dividends and debt. Review of Financial Studies 15, 1-33.

Fama, E.F., Jensen, M.C., 1983. Agency problems and residual claims. Journal of Law and Economics 26, $327-$ 349.

Fama, E.F., MacBeth, J., 1973. Risk, return and equilibrium: Empirical tests. Journal of Political Economy 81, 607-636.

Fich, E.M., 2005. Are some outside directors better than others? Evidence from director appointments by fortune 1000 firms. Journal of Business 78, 1943-1972.

Finkelstein, S., Ann, C.M., 2003. Not the usual suspects: How to use board process to make boards below. The Academy of Management Executive 17, 101-113.

Firth, M., 1995. The impact of insitutional stockholders and magerial interests on the capital structure of firms. Managerial and Decision Economics 16, 167-175.

Friend, I., Hasbrouck, 1988. Determinants of capital structure. Research in Finance 7, 1-19.

Friend, I., Lang, L.H.P., 1988. An empirical test of the impact of managerial self-interest on corporate capital structure. Journal of Finance 43, 271-281.

Gillan, S., Starks, L.T., 1998. A survey of shareholder activism: Motivation and empirical evidence. Available at SSRN 663523.

Graham, J.R., 1996. Debt and the marginal tax rate. Journal of Financial Economics 41, 41-73.

Graham, J.R., Tucker, A.L., 2006. Tax shelters and corporate debt policy. Journal of Financial Economics 81, 563-594.

Guner, A.B., Malmendierb, U., Tate, G., 2008. Financial expertise of directors. Journal of Financial Economics $88,323-354$.

Hair, J.F., Black, W.C., Babin, B.J., Anderson, R.E., Tatham, R.L., 2006. Multivariate Data Analysis (6 ${ }^{\text {th }}$ Edition). Pearson Prentice-Hall, Upper Saddle River, NJ.

Hanlon, M., Heitzman, S., 2010. A review of tax research. Journal of Accounting and Economics 50, 127-178.

Harris, M., Raviv, A., 1991. The theory of capital structure. Journal of Finance 46, 297-355.

Hartford, J., Li, K., Zhao, X., 2008. Corporate boards and the leverage and debt maturity choices. International Journal of Corporate Governance 1, 3-27.

Hasan, I., Hoi, C.K.S., Wu, Q., Zhang, H., 2014. Beauty is in the eye of the beholder: The effect of corporate tax avoidance on the cost of bank loans. Journal of Financial Economics 113, 109-130.

Hausman, J., 1978. Specification tests in econometrics. Econometrica 41, 1251-1271.

Hermalin, B., Weisbach, M., 1991. The effect of board composition and direct incentives on firm performance. Financial Management 20, 101-112.

Hoi, C.K., Wu, Q., Zhang, H., 2013. Is corporate social responsibility (CSR) related with tax avoidance? Evidence from irresponsible CSR activities. The Accounting Review 88, 2025-2059. 
Kaplan, S.N., Minton, B.A., 1994. Appointments of outsiders to Japanese boards: Determinants and implications for managers. Journal of Financial Economics 36, 225-258.

Kroszner, R.S., Strahan, P.E., 2001. Bankers on boards: Monitoring, conflicts of interest, and lender liability. Journal of Financial Economics 62, 415-452.

Lanis, R., Richardson, G., 2011. The effect of board of director composition on corporate tax avoidance. Journal of Accounting and Public Policy 30, 50-70.

Lehn, K.M., Patro, S., Zhao, M., 2009. Determinants of the size and composition of us corporate boards: $1935-$ 2000. Financial Management 38, 747-780.

Lim, Y., 2011. Tax avoidance, cost of debt and shareholder activism: Evidence from Korea. Journal of Banking and Finance 35, 456-470.

Mace, M., L., 1971. Directors: Myth and reality. Working Paper Boston: Harvard University.

MacKie-Mason, J.K., 1990. Do taxes affect corporate financing decisions? Journal of Finance 45, 1471-1493.

Malmendier, U., Shanthikumar, D., 2007. Are small investors naive about incentives? Journal of Financial Economics 85, 457-489.

McGuire, S.T., Omer, T.C., Wang, D., 2012. Tax avoidance: Does tax-specific industry expertise make a difference? The Accounting Review 87, 975-1003.

Myers, S.C., 1984. The capital structure puzzle. Journal of Finance 39, 575-592.

Rajan, R., G., Zingales, L., 1995. What do we know about capital structure? Some evidence from international data. Journal of Finance 50, 1421-1460.

Reuter, J., 2006. Are IPO allocations for sale? Evidence from mutual funds. Journal of Finance 65, 1540-6261.

Richardson, G., Lanis, R., Leung, S.C.-M., 2014. Corporate tax avoidance, outside directors, and debt policy: An empirical analysis. Journal of Corporate Finance 25, 107-121.

Roberts, M.R., Whited, T.M., 2013. Endogeneity in empirical corporate finance. Handbook of the Economics of Finance, Constantinides, G.M., Harris, M., and Stulz, R.M., Eds. North Holland, Oxford, UK (Vol. 2A, Corporate Finance, pp.493-572).

Rosenstein, S., Wyatt, J.G., 1990. Outside directors, board independence, and shareholder wealth. Journal of Financial Economics 26, 175-191.

Stulz, R.M., 1988. Managerial control of voting rights: Financing policies and the market for coporate control. Journal of Financial Economics 20, 25-54.

Vance, S.C., 1978. Corporate governance: Assessing corporate performance by boardroom attributes. Journal of Business Research 6, 203-220.

Williamson, O.E., 1984. Corporate governance. Yale Law Journal 1197, Faculty Scholarship Series Paper 4392.

Wilson, R.J., 2009. An Examination of Corporate Tax Shelter Participants. The Accounting Review 84, 969-999.

Wooldridge, J.M., 2010. Econometric Analysis of Cross Section and Panel Data (2 ${ }^{\text {nd }}$ Edition). MIT Press, Cambridge, MA.Yermack, D., 1996. Higher market valuation of companies with a small board of directors. The Journal of Financial Economics 40, 185-211. 
Table 1

Sample industry distribution

\begin{tabular}{lccccccc}
\hline \multirow{2}{*}{ Industry description } & GICS & \multicolumn{2}{c}{ ETR(1yr) } & \multicolumn{2}{c}{ ETR(3yr) } & \multicolumn{2}{c}{ ETR(5YR) } \\
\cline { 3 - 8 } & Code & Obs. & $\begin{array}{c}\text { Frequency } \\
\%\end{array}$ & Obs. & $\begin{array}{c}\text { Frequency } \\
\%\end{array}$ & Obs. & $\begin{array}{c}\text { Frequency } \\
\%\end{array}$ \\
\hline Energy & 10 & 90 & 2.76 & 82 & 2.98 & 64 & 3.27 \\
Materials & 15 & 353 & 10.81 & 308 & 11.20 & 236 & 12.05 \\
Industrials & 20 & 662 & 20.28 & 574 & 20.87 & 412 & 21.03 \\
Consumer discretionary & 25 & 445 & 13.63 & 360 & 13.09 & 247 & 12.61 \\
Consumer staples & 30 & 122 & 3.74 & 105 & 3.82 & 79 & 4.03 \\
Health care & 35 & 658 & 20.16 & 546 & 19.85 & 385 & 19.65 \\
Information Technology & 45 & 887 & 27.18 & 737 & 26.80 & 509 & 25.98 \\
Telecommunications & 50 & 47 & 1.44 & 38 & 1.38 & 27 & 1.38 \\
\hline Total & & 3,264 & 100.00 & 2,750 & 100.00 & 1,959 & 100.00 \\
\hline
\end{tabular}


Table 2

Variable definitions

\begin{tabular}{|c|c|}
\hline Variable & Definition \\
\hline \multicolumn{2}{|c|}{ Dependent Variable } \\
\hline MDEBT & $\begin{array}{l}=\text { total debt }(\# \mathrm{dlc}+\# \mathrm{dltt}) \text { divided by the sum of the market value of equity and total debt }((\# \text { ceq }+ \\
\# \text { tstkp }-\# \text { dvpa })+(\# \text { dlc }+\# \text { dltt }))\end{array}$ \\
\hline \multicolumn{2}{|c|}{ Independent Variables } \\
\hline \multicolumn{2}{|c|}{ Tax avoidance } \\
\hline $\operatorname{ETR}_{(1 \mathrm{yr})}$ & $=(1-$ minus tax paid $(\#$ txpd $)$ divided by pre-tax earnings $(\# p i)$ over one year $)$ \\
\hline $\operatorname{ETR}_{(3 \mathrm{yr})}$ & $=(1-$ minus tax paid $(\#$ txpd $)$ divided by pre-tax earnings $(\#$ pi) over a three-year period $)$ \\
\hline $\operatorname{ETR}_{(5 \mathrm{yr})}$ & $=(1-$ minus tax paid (\#txpd) divided by pre-tax earnings (\#pi) over a five-year period) \\
\hline \multicolumn{2}{|c|}{ Board Expertise: $\mathrm{i}=$ independent director; $\mathrm{d}=$ inside director } \\
\hline iFinancial & $\begin{array}{l}=1 \text { which denotes an INDEPENDENT director with a financial degree (e.g., BCom or MBA) or with } \\
\text { professional qualifications that include finance and tax (e.g., CPA) }\end{array}$ \\
\hline iLaw & $\begin{array}{l}=1 \text { which denotes an INDEPENDENT director with legal education or professional qualifications } \\
\text { that is likely to include tax expertise. }\end{array}$ \\
\hline dFinancial & $\begin{array}{l}=1 \text { which denotes an INSIDE (inside) director with a financial degree (e.g., BCom or MBA) or with } \\
\text { professional qualifications that include finance and tax (e.g., CPA) }\end{array}$ \\
\hline dLaw & $\begin{array}{l}=1 \text { which denotes an INSIDE (inside) director with legal education or professional qualifications } \\
\text { that is likely to include tax expertise. }\end{array}$ \\
\hline \multicolumn{2}{|c|}{ Control Variables } \\
\hline OI & $=$ operating income divided by total assets (\#at) \\
\hline MB & $\begin{array}{l}=\text { the market capitalization of outstanding shares }\left(\# p r c c \_f^{*} \# c s h o\right) \text { divided by book value of net } \\
\text { assets }(\# c e q+\# t s t k p-\# d v p a)\end{array}$ \\
\hline LnA & $\begin{array}{l}=\log \text { of total assets }(\log \# \text { at) } \\
=\text { depreciation and amortization divided by total assets }(\# \text { at) }\end{array}$ \\
\hline DEP & $=$ depreciation and amortization divided by total assets (\#at) \\
\hline FA & $=$ fixed assets (\#ppent) divided by total assets (\#at) \\
\hline RND & $=\mathrm{R} \& \mathrm{D}$ expenditure divided by net sales (\#sale) \\
\hline DIV & $=$ common stock dividends $(\#$ dvc) divided by total assets (\#at) \\
\hline $\mathrm{AZ}$ & 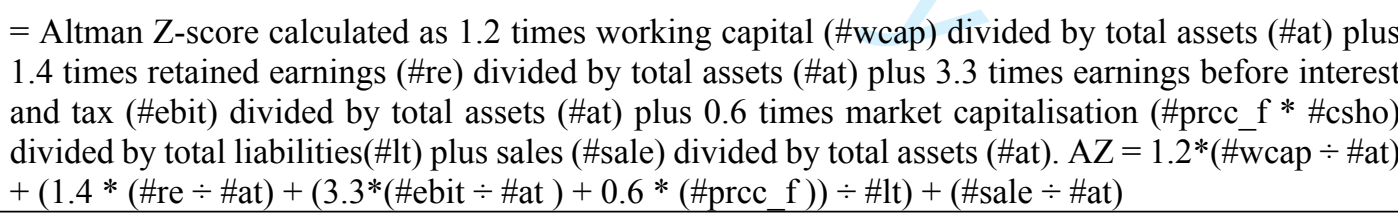 \\
\hline
\end{tabular}

Notes: Data items comprising financial statement variables from the Compustat Database sourced in WRDS

\begin{tabular}{lll}
\hline Variable & & Definition \\
\hline \#at & $=$ total assets \\
\#ceq & $=$ book value of common ordinary equity \\
\#csho & $=$ net number of ordinary shares on issue \\
\#dlc & $=$ debt minus current liabilities \\
$\#$ dltt & $=$ debt minus long-term liabilities \\
$\#$ dvc & $=$ common stock dividends \\
$\#$ dvpa & $=$ preferred dividends in arrears \\
\#ebit & $=$ earnings before interest and taxes \\
\#lt & $=$ total liabilities
\end{tabular}




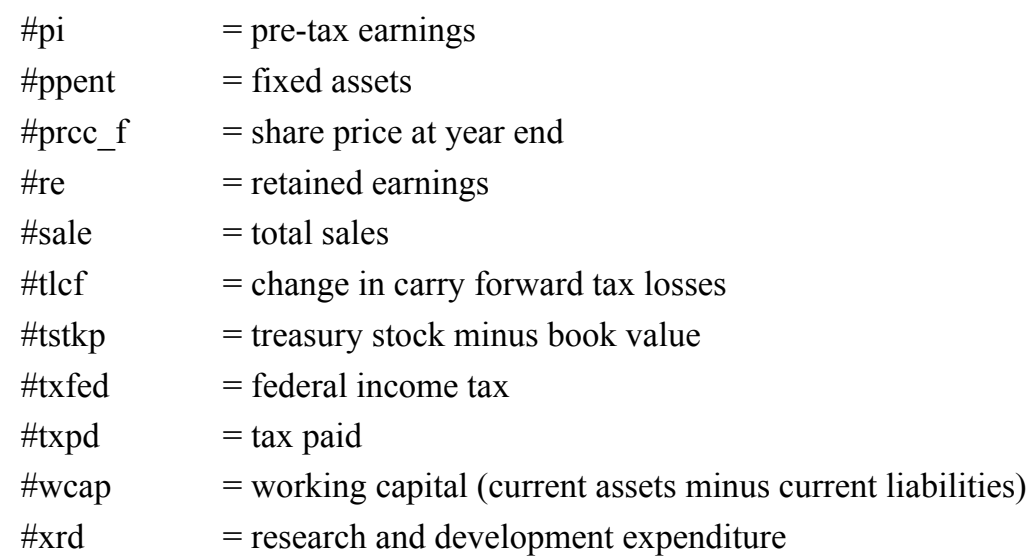


Table 3

Descriptive statistics

\begin{tabular}{lcccccccc}
\hline Variable & Obs. & Mean & Std. Dev. & Min & p25 & Median & p75 & Max \\
\hline MDEBT & 3,264 & 0.249 & 0.227 & 0.000 & 0.015 & 0.230 & 0.398 & 0.934 \\
ETR(1yr) & 3,264 & 0.758 & 0.242 & -0.944 & 0.666 & 0.770 & 0.901 & 2.222 \\
ETR(3yr) & 2,750 & 0.736 & 0.217 & -0.951 & 0.661 & 0.752 & 0.853 & 2.284 \\
ETR(5yr) & 1,959 & 0.710 & 0.244 & -1.042 & 0.662 & 0.735 & 0.830 & 2.581 \\
iFinancial & 3,264 & 0.189 & 0.179 & 0.000 & 0.000 & 0.167 & 0.286 & 0.800 \\
iLaw & 3,264 & 0.024 & 0.064 & 0.000 & 0.000 & 0.000 & 0.000 & 0.500 \\
iOther & 3,264 & 0.383 & 0.262 & 0.000 & 0.200 & 0.400 & 0.556 & 1.000 \\
dFinancial & 3,264 & 0.101 & 0.153 & 0.000 & 0.000 & 0.000 & 0.143 & 1.000 \\
dLaw & 3,264 & 0.016 & 0.060 & 0.000 & 0.000 & 0.000 & 0.000 & 0.400 \\
dOther & 3,264 & 0.351 & 0.306 & 0.000 & 0.118 & 0.273 & 0.500 & 1.000 \\
OI & 3,264 & 0.150 & 0.074 & -0.441 & 0.102 & 0.136 & 0.182 & 0.421 \\
MB & 3,264 & 3.430 & 3.166 & 0.393 & 1.748 & 2.546 & 3.877 & 27.098 \\
LnA & 3,264 & 6.998 & 1.640 & 2.487 & 5.870 & 6.892 & 8.046 & 10.930 \\
DEP & 3,264 & 0.036 & 0.020 & 0.001 & 0.023 & 0.033 & 0.046 & 0.162 \\
FA & 3,264 & 0.204 & 0.168 & 0.000 & 0.077 & 0.156 & 0.287 & 0.895 \\
RND & 3,264 & 0.066 & 0.283 & 0.000 & 0.006 & 0.026 & 0.086 & 15.504 \\
DIV & 3,264 & 0.011 & 0.020 & 0.000 & 0.000 & 0.000 & 0.015 & 0.154 \\
AZ & 3,264 & 5.863 & 5.678 & -9.760 & 2.699 & 3.992 & 6.896 & 36.917 \\
\hline
\end{tabular}

Variable definitions: All variables are defined in Table 2. 
Table 4

Pearson correlation results

\begin{tabular}{|c|c|c|c|c|c|c|c|c|c|c|c|c|c|c|c|c|c|c|}
\hline & MDEBT & ETR(1yr) & ETR(3yr) & ETR(5yr) & iFinancial & iLaw & iOther & dFinancial & dLaw & dOther & OI & $\mathrm{M} / \mathrm{B}$ & $\operatorname{LnA}$ & DEP & $\overline{F A}$ & RND & DIV & $\overline{\mathrm{AZ}}$ \\
\hline MDEBT & 1.000 & & & & & & & & & & & & & & & & & \\
\hline ETR(1yr) & -0.040 & 1.000 & & & & & & & & & & & & & & & & \\
\hline ETR(3yr) & -0.019 & 0.025 & 1.000 & & & & & & & & & & & & & & & \\
\hline ETR(5yr) & 0.004 & 0.032 & 0.012 & 1.000 & & & & & & & & & & & & & & \\
\hline iFinancial & $0.054^{*}$ & 0.037 & -0.002 & -0.002 & 1.000 & & & & & & & & & & & & & \\
\hline iLaw & $0.079 * * *$ & 0.003 & -0.014 & 0.004 & -0.032 & 1.000 & & & & & & & & & & & & \\
\hline iOther & -0.008 & -0.031 & 0.020 & 0.037 & $0.088^{* * *}$ & $0.107 * * *$ & 1.000 & & & & & & & & & & & \\
\hline dFinancial & $0.111^{* * *}$ & 0.031 & 0.004 & 0.004 & $-0.251^{* * *}$ & $-0.114 * * *$ & $-0.417 * * *$ & 1.000 & & & & & & & & & & \\
\hline dLaw & $0.101 * * *$ & -0.009 & -0.027 & -0.005 & $-0.172 * * *$ & $-0.069^{* *}$ & $-0.204 * * *$ & -0.037 & 1.000 & & & & & & & & & \\
\hline dOther & $-0.071^{* *}$ & 0.018 & -0.003 & -0.026 & $-0.559^{* * *}$ & $-0.241^{* * *}$ & $-0.771^{* * *}$ & $0.357^{* * *}$ & $0.071^{* *}$ & 1.000 & & & & & & & & \\
\hline OI & $-0.088^{* * *}$ & $-0.049 *$ & 0.015 & -0.016 & $0.082 * * *$ & 0.020 & -0.012 & 0.027 & -0.028 & -0.030 & 1.000 & & & & & & & \\
\hline $\mathrm{M} / \mathrm{B}$ & $0.256^{* * *}$ & $0.051^{*}$ & -0.013 & 0.003 & $0.065^{* *}$ & -0.012 & 0.020 & 0.009 & $-0.068^{* *}$ & -0.020 & $0.463 * * *$ & 1.000 & & & & & & \\
\hline LnA & $0.413 * * *$ & -0.034 & -0.020 & -0.016 & 0.001 & $0.088^{* * *}$ & $0.125 * * *$ & 0.020 & $0.064 * *$ & $-0.117 * * *$ & -0.033 & 0.026 & 1.000 & & & & & \\
\hline DEP & $0.044^{*}$ & $-0.050^{*}$ & -0.030 & -0.014 & -0.001 & 0.003 & -0.031 & 0.016 & $0.046^{*}$ & 0.011 & $0.300^{* * *}$ & $0.101 * * *$ & $-0.052^{*}$ & 1.000 & & & & \\
\hline FA & $0.236^{* * *}$ & -0.040 & -0.017 & 0.002 & $-0.065^{* *}$ & $0.056^{*}$ & $-0.077 * * *$ & $0.101 * * *$ & $0.049^{*}$ & 0.041 & $0.160 * * *$ & 0.017 & $0.058 * *$ & $0.551 * * *$ & 1.000 & & & \\
\hline RND & $-0.319 * * *$ & $0.093^{* * *}$ & 0.034 & 0.020 & $-0.044^{*}$ & $-0.099 * * *$ & $0.077 * * *$ & $-0.076^{* * *}$ & $-0.118 * * *$ & $0.047^{*}$ & $-0.123^{* * *}$ & $0.051^{*}$ & $-0.127 * * *$ & $-0.079 * * *$ & $-0.365^{* * *}$ & 1.000 & & \\
\hline DIV & 0.019 & $-0.086^{* * *}$ & -0.021 & -0.021 & 0.024 & $0.067^{* *}$ & $0.058^{* *}$ & $-0.066^{* *}$ & -0.018 & $-0.060^{* *}$ & $0.344 * * *$ & $0.201 * * *$ & $0.109 * * *$ & $0.094 * * *$ & $0.151^{* * *}$ & $-0.118^{* * *}$ & 1.000 & \\
\hline $\mathrm{AZ}$ & $-0.506 * * *$ & 0.023 & 0.009 & -0.009 & $-0.050^{*}$ & $-0.075^{* * *}$ & -0.027 & -0.033 & $-0.106 * * *$ & $0.097 * * *$ & $0.399 * * *$ & $0.191 * * *$ & $-0.258 * * *$ & $-0.064 * *$ & $-0.114 * * *$ & $0.200^{* * *}$ & $0.169^{* * *}$ & 1.000 \\
\hline
\end{tabular}

Variable definitions: All variables are defined in Table 2.

$* p<0.10,{ }^{* *} p<0.05, * * * p<0.010$. 
Table 5

Regressions results - financial expertise of directors and corporate debt

Panel A: Outside directors (H1a)

\begin{tabular}{|c|c|c|c|c|c|c|c|}
\hline Variable & Pred. Sign & Coef. & $t$-stat. & Coef. & $t$-stat. & Coef. & $t$-stat. \\
\hline ETR(1yr) & - & -0.026 & $-1.810^{*}$ & & & & \\
\hline ETR(3yr) & - & & & -0.055 & $-3.453 * * *$ & & \\
\hline $\operatorname{ETR}(5 y r)$ & - & & & & & -0.042 & $-2.203 * *$ \\
\hline iFinancial & $?$ & 0.015 & 1.112 & 0.024 & $1.720 *$ & 0.017 & 1.012 \\
\hline iLaw & $?$ & -0.009 & -0.776 & -0.004 & -0.318 & 0.003 & -0.212 \\
\hline OI & - & -0.123 & $-7.680 * * *$ & -0.092 & $-4.950 * * *$ & -0.049 & $-2.178 * *$ \\
\hline MB & + & 0.377 & $23.470 * * *$ & 0.388 & $23.443 * * *$ & 0.396 & $19.421 * * *$ \\
\hline LnA & + & 0.258 & $19.878 * * *$ & 0.250 & $18.035^{* * *}$ & 0.260 & $15.142 * * *$ \\
\hline DEP & - & -0.077 & $-4.429 * * *$ & -0.083 & $-4.364 * * *$ & -0.085 & $-3.711 * * *$ \\
\hline FA & + & 0.129 & $6.702 * * *$ & 0.129 & $6.007 * * *$ & 0.109 & $4.153 * * *$ \\
\hline RND & $?$ & -0.044 & $-1.785^{*}$ & -0.031 & $-2.760 * * *$ & -0.022 & -1.311 \\
\hline DIV & - & -0.051 & $-3.959 * * *$ & -0.059 & $-4.172 * * *$ & -0.067 & $-3.739 * * *$ \\
\hline $\mathrm{AZ}$ & - & -0.411 & $-22.261 * * *$ & -0.432 & $-19.608 * * *$ & -0.427 & $-15.469 * * *$ \\
\hline Constant & $?$ & 0.028 & 0.59 & 0.014 & 0.323 & -0.093 & $-2.042 * *$ \\
\hline Year Effects & $?$ & Yes & & Yes & & Yes & \\
\hline Industry Effects & $?$ & Yes & & Yes & & Yes & \\
\hline Observations & & 3,264 & & 2,750 & & 1,959 & \\
\hline Adj. $R^{2}$ & & 0.539 & & 0.544 & & 0.548 & \\
\hline
\end{tabular}

Panel B: Inside directors (H1b)

\begin{tabular}{|c|c|c|c|c|c|c|c|}
\hline Variable & Pred. Sign & Coef. & $t$-stat. & Coef. & $t$-stat. & Coef. & $t$-stat. \\
\hline ETR(1yr) & - & -0.027 & $-1.898 *$ & & & & \\
\hline $\operatorname{ETR}(3 y r)$ & - & & & -0.055 & $-3.463 * * *$ & & \\
\hline $\operatorname{ETR}(5 y r)$ & - & & & & & -0.042 & $-2.186^{* *}$ \\
\hline dFinancial & $?$ & 0.041 & $3.237 * * *$ & 0.044 & $3.202 * * *$ & 0.051 & $3.258 * * *$ \\
\hline dLaw & $?$ & 0.019 & 1.598 & 0.000 & $2.704 * * *$ & 0.049 & $3.429 * * *$ \\
\hline OI & - & -0.122 & $-7.597 * * *$ & -0.090 & $-4.845 * * *$ & -0.049 & $-2.193 * *$ \\
\hline $\mathrm{MB}$ & + & 0.380 & $23.796 * * *$ & 0.392 & $23.564 * * *$ & 0.400 & $19.531 * * *$ \\
\hline $\operatorname{Ln} A$ & + & 0.257 & $19.973 * * *$ & 0.249 & $17.935 * * *$ & 0.259 & $15.205^{* * *}$ \\
\hline
\end{tabular}




\begin{tabular}{|c|c|c|c|c|c|c|c|}
\hline DEP & - & -0.075 & $-4.342 * * *$ & -0.083 & $-4.401 * * *$ & -0.087 & $-3.769 * * *$ \\
\hline FA & + & 0.120 & $6.380 * * *$ & 0.121 & $5.671 * * *$ & 0.102 & $3.953 * * *$ \\
\hline RND & $?$ & -0.044 & $-1.811^{*}$ & -0.031 & $-2.865 * * *$ & -0.021 & -1.365 \\
\hline DIV & - & -0.050 & $-3.933 * * *$ & -0.057 & $-4.008 * * *$ & -0.062 & $-3.501 * * *$ \\
\hline $\mathrm{AZ}$ & - & -0.410 & $-22.308 * * *$ & -0.430 & $-19.631 * * *$ & -0.423 & $-15.587 * * *$ \\
\hline Constant & $?$ & 0.020 & 0.428 & 0.011 & 0.263 & -0.096 & $-2.094 * *$ \\
\hline Year Effects & $?$ & Yes & & Yes & & Yes & \\
\hline Industry Effects & $?$ & Yes & & Yes & & Yes & \\
\hline Observations & & 3264 & & 2750 & & 1959 & \\
\hline Adj. $\mathrm{R}^{2}$ & & 0.541 & & 0.547 & & 0.553 & \\
\hline
\end{tabular}

Standardized beta coefficients with robust $t$-statistics (Wooldridge, 2010) in adjacent columns. Variable definitions: All variables are defined in Table 2.

$* p<0.10, * * p<0.05, * * * p<0.010$. 
Table 6

Regressions results - debt-substitution effect and outside/inside directors

Panel A: Outside directors (H2a)

\begin{tabular}{|c|c|c|c|c|c|c|c|}
\hline Variable & Pred. Sign & Coef. & $t$-stat. & Coef. & $t$-stat. & Coef. & $t$-stat. \\
\hline $\operatorname{ETR}(1 \mathrm{yr})$ & - & -0.029 & $-2.068 * *$ & & & & \\
\hline $\operatorname{ETR}(1 \mathrm{yr}) *$ iFinancial & - & -0.040 & $-2.921 * * *$ & & & & \\
\hline $\operatorname{ETR}(1 \mathrm{yr}) * \mathrm{iLaw}$ & - & 0.009 & 0.741 & & & & \\
\hline $\operatorname{ETR}(3 y r)$ & - & & & -0.056 & $-3.469 * * *$ & & \\
\hline $\operatorname{ETR}(3 y r) *$ iFinancial & - & & & -0.035 & $-2.310 * *$ & & \\
\hline $\operatorname{ETR}(3 \mathrm{yr}) * \mathrm{iLaw}$ & - & & & 0.007 & 0.484 & & \\
\hline $\operatorname{ETR}(5 y r)$ & - & & & & & -0.040 & $-2.134 * *$ \\
\hline $\operatorname{ETR}(5 y r) \times$ iFinancial & - & & & & & -0.023 & -1.067 \\
\hline $\operatorname{ETR}(5 y r) \times$ iLaw & - & & & & & -0.001 & -0.036 \\
\hline iFinancial & $?$ & 0.014 & -1.072 & 0.026 & $1.878^{*}$ & 0.017 & 0.999 \\
\hline iLaw & $?$ & -0.009 & -0.790 & -0.004 & -0.327 & 0.003 & 0.205 \\
\hline OI & - & -0.125 & $-7.750 * * *$ & -0.092 & $-4.969 * * *$ & -0.048 & $-2.120 * *$ \\
\hline MB & + & 0.377 & $23.430 * * *$ & 0.386 & $23.211 * * *$ & 0.396 & $19.415^{* * *}$ \\
\hline $\operatorname{LnA}$ & + & 0.257 & $19.873 * * *$ & 0.250 & $18.041 * * *$ & 0.259 & $15.144 * * *$ \\
\hline DEP & - & -0.076 & $-4.373 * * *$ & -0.085 & $-4.473 * * *$ & -0.088 & $-3.955^{* * *}$ \\
\hline FA & + & 0.129 & $6.742 * * *$ & 0.131 & $6.089 * * *$ & 0.111 & $4.249 * * *$ \\
\hline RND & $?$ & -0.044 & $-1.787^{*}$ & -0.030 & $-2.559 * *$ & -0.021 & -1.085 \\
\hline DIV & - & -0.051 & $-3.966 * * *$ & -0.060 & $-4.220 * * *$ & -0.067 & $-3.726 * * *$ \\
\hline $\mathrm{AZ}$ & - & -0.411 & $-22.278 * * *$ & -0.432 & $-19.639 * * *$ & -0.428 & $-15.461 * * *$ \\
\hline Constant & $?$ & 0.003 & 0.067 & -0.009 & -0.203 & -0.108 & $-2.269 * *$ \\
\hline Year Effects & $?$ & Yes & & Yes & & Yes & \\
\hline Industry Effects & $?$ & Yes & & Yes & & Yes & \\
\hline Observations & & 3,264 & & 2,750 & & 1,959 & \\
\hline Adj. $R^{2}$ & & 0.540 & & 0.545 & & 0.548 & \\
\hline
\end{tabular}

Panel B: Inside Directors (H2b)

\begin{tabular}{|c|c|c|c|c|c|c|c|}
\hline Variable & Pred. Sign & Coef. & $t$-stat. & Coef. & $t$-stat. & Coef. & $t$-stat. \\
\hline $\operatorname{ETR}(1 \mathrm{yr})$ & - & -0.029 & $-2.069 * *$ & & & & \\
\hline $\operatorname{ETR}(1 \mathrm{yr}) *$ dFinancial & - & -0.015 & -1.141 & & & & \\
\hline $\operatorname{ETR}(1 \mathrm{yr}) * \mathrm{dLaw}$ & - & 0.001 & 0.043 & & & & \\
\hline ETR(3yr) & - & & & -0.049 & $-3.119 * * *$ & & \\
\hline $\operatorname{ETR}(3 y r) *$ dFinancial & - & & & -0.008 & -0.447 & & \\
\hline
\end{tabular}




\begin{tabular}{|c|c|c|c|c|c|c|c|}
\hline $\operatorname{ETR}(3 y r) *$ dLaw & - & & & -0.036 & $-2.215 * *$ & & \\
\hline $\operatorname{ETR}(5 y r)$ & - & & & & & -0.043 & $-2.222 * *$ \\
\hline $\operatorname{ETR}(5 \mathrm{yr}) *$ dFinancial & - & & & & & 0.010 & 0.501 \\
\hline $\operatorname{ETR}(5 \mathrm{yr}) * \mathrm{dLaw}$ & - & & & & & -0.013 & -0.797 \\
\hline dFinancial & $?$ & 0.042 & $3.317 * * *$ & 0.045 & $3.246^{* * *}$ & 0.051 & $3.240 * * *$ \\
\hline dLaw & $?$ & 0.018 & 1.587 & 0.032 & $2.561 * *$ & 0.049 & $3.384 * * *$ \\
\hline $\mathrm{OI}$ & - & -0.122 & $-7.629 * * *$ & -0.089 & $-4.836 * * *$ & -0.048 & $-2.174 * *$ \\
\hline $\mathrm{MB}$ & + & 0.380 & $23.782 * * *$ & 0.391 & $23.620 * * *$ & 0.399 & $19.572 * * *$ \\
\hline $\operatorname{Ln} A$ & + & 0.257 & $20.005 * * *$ & 0.249 & $17.997 * * *$ & 0.260 & $15.218 * * *$ \\
\hline DEP & - & -0.075 & $-4.341 * * *$ & -0.083 & $-4.354 * * *$ & -0.086 & $-3.741 * * *$ \\
\hline FA & + & 0.121 & $6.385^{* * *}$ & 0.119 & $5.582 * * *$ & 0.101 & $3.900 * * *$ \\
\hline RND & $?$ & -0.044 & $-1.809 *$ & -0.030 & $-2.701 * * *$ & -0.022 & -1.380 \\
\hline DIV & - & -0.050 & $-3.911 * * *$ & -0.057 & $-3.990 * * *$ & -0.062 & $-3.487 * * *$ \\
\hline $\mathrm{AZ}$ & - & -0.410 & $-22.287 * * *$ & -0.430 & $-19.635 * * *$ & -0.423 & $-15.577 * * *$ \\
\hline Constant & $?$ & 0.015 & 0.309 & -0.004 & -0.083 & -0.094 & $-2.009 * *$ \\
\hline Year Effects & $?$ & Yes & & Yes & & Yes & \\
\hline Industry Effects & $?$ & Yes & & Yes & & Yes & \\
\hline Observations & & 3,264 & & 2,750 & & 1,959 & \\
\hline Adj. $\mathrm{R}^{2}$ & & 0.540 & & 0.548 & & 0.552 & \\
\hline
\end{tabular}

Standardized beta coefficients with robust $t$-statistics (Wooldridge, 2010) in adjacent columns.

Variable definitions: All variables are defined in Table 2.

$* p<0.10, * * p<0.05, * * * p<0.010$. 
Table 7

Regression results - financial expertise of directors and corporate debt (lagged explanatory variables)

Panel A: Outside directors (H1a)

\begin{tabular}{|c|c|c|c|c|c|c|c|}
\hline Variable & Pred. Sign & Coef. & $t$-stat. & Coef. & $t$-stat. & Coef. & $t$-stat. \\
\hline ETR(1yr) & - & -0.033 & $-2.317 * *$ & & & & \\
\hline ETR(3yr) & - & & & -0.055 & $-3.062 * * *$ & & \\
\hline $\operatorname{ETR}(5 y r)$ & - & & & & & -0.041 & $-1.960 *$ \\
\hline iFinancial & $?$ & 0.030 & 1.634 & 0.027 & 1.283 & 0.02 & 0.75 \\
\hline iLaw & $?$ & -0.033 & -0.705 & -0.001 & -0.028 & 0.014 & 0.215 \\
\hline OI & - & -0.218 & $-3.678 * * *$ & -0.149 & $-2.302 * *$ & -0.048 & -0.672 \\
\hline MB & + & 0.021 & $13.554 * * *$ & 0.023 & $11.700 * * *$ & 0.024 & $9.859 * * *$ \\
\hline $\operatorname{LnA}$ & + & 0.036 & $17.802 * * *$ & 0.034 & $14.897 * * *$ & 0.037 & $13.822 * * *$ \\
\hline DEP & - & -0.859 & $-3.900 * * *$ & -0.898 & $-3.267 * * *$ & -0.899 & $-2.852 * * *$ \\
\hline FA & + & 0.156 & $5.391 * * *$ & 0.151 & $4.413 * * *$ & 0.138 & $3.421 * * *$ \\
\hline RND & $?$ & -0.024 & -1.422 & -0.010 & $-1.856^{*}$ & -0.008 & -0.879 \\
\hline DIV & - & -0.682 & $-3.612 * * *$ & -0.689 & $-3.453 * * *$ & -0.745 & $-3.383 * * *$ \\
\hline $\mathrm{AZ}$ & - & -0.015 & $-20.359 * * *$ & -0.016 & $-17.770 * * *$ & -0.017 & $-14.314 * * *$ \\
\hline Constant & $?$ & 0.008 & 0.169 & -0.007 & -0.157 & -0.122 & $-2.656 * * *$ \\
\hline Year Effects & $?$ & Yes & & Yes & & Yes & \\
\hline Firm Effects & $?$ & Yes & & Yes & & Yes & \\
\hline Observations & & 2,777 & & 2,296 & & 1,641 & \\
\hline Adj. $R^{2}$ & & 0.473 & & 0.472 & & 0.493 & \\
\hline
\end{tabular}

Panel B: Inside directors (H1b)

\begin{tabular}{|c|c|c|c|c|c|c|c|}
\hline Variable & Pred. Sign & Coef. & $t$-stat. & Coef. & $t$-stat. & Coef. & $t$-stat. \\
\hline $\operatorname{ETR}(1 \mathrm{yr})$ & - & -0.034 & $-2.380 * *$ & & & & \\
\hline $\operatorname{ETR}(3 y r)$ & - & & & -0.054 & $-3.030 * * *$ & & \\
\hline $\operatorname{ETR}(5 y r)$ & - & & & & & -0.041 & $-1.943 *$ \\
\hline dFinancial & $?$ & 0.082 & $3.749 * * *$ & 0.082 & $3.361 * * *$ & 0.081 & $2.894 * * *$ \\
\hline dLaw & $?$ & 0.102 & $2.067 * *$ & 0.155 & $3.034 * * *$ & 0.216 & $3.838 * * *$ \\
\hline OI & - & -0.211 & $-3.558 * * *$ & -0.143 & $-2.222 * *$ & -0.048 & -0.665 \\
\hline MB & + & 0.022 & $13.900 * * *$ & 0.024 & $11.887 * * *$ & 0.024 & $9.994 * * *$ \\
\hline $\operatorname{LnA}$ & + & 0.036 & $17.777 * * *$ & 0.034 & $14.775^{* * *}$ & 0.037 & $13.882 * * *$ \\
\hline DEP & - & -0.852 & $-3.886 * * *$ & -0.919 & $-3.353 * * *$ & -0.925 & $-2.934 * * *$ \\
\hline FA & + & 0.142 & $4.965 * * *$ & 0.140 & $4.131 * * *$ & 0.13 & $3.275^{* * *}$ \\
\hline RND & $?$ & -0.024 & -1.468 & -0.010 & $-1.936^{*}$ & -0.009 & -0.922 \\
\hline DIV & - & -0.649 & $-3.450 * * *$ & -0.65 & $-3.284 * * *$ & -0.681 & $-3.121 * * *$ \\
\hline $\mathrm{AZ}$ & - & -0.015 & $-20.470 * * *$ & -0.016 & $-17.830 * * *$ & -0.017 & $-14.481 * * *$ \\
\hline Constant & $?$ & 0.000 & -0.006 & -0.011 & -0.243 & -0.125 & $-2.744 * * *$ \\
\hline Year Effects & $?$ & Yes & & Yes & & Yes & \\
\hline $\begin{array}{l}\text { Industry } \\
\text { Effects }\end{array}$ & $?$ & Yes & & Yes & & Yes & \\
\hline Observations & & 2,777 & & 2,296 & & 1,641 & \\
\hline
\end{tabular}


Adj. $R^{2}$ 0.476

0.476

Standardized beta coefficients with robust $t$-statistics (Wooldridge, 2010) in adjacent columns. Variable definitions: All variables are defined in Table 2.

$* p<0.10, * * p<0.05, * * * p<0.010$. 
Table 8

Regression results - debt-substitution effect and outside/inside directors (lagged explanatory variables)

Panel A: Outside directors (H2a)

\begin{tabular}{|c|c|c|c|c|c|c|c|}
\hline Variable & Pred. Sign & Coef. & $t$-stat. & Coef. & $t$-stat. & Coef. & $t$-stat. \\
\hline $\operatorname{ETR}(1 \mathrm{yr})$ & - & 0.010 & 0.543 & & & & \\
\hline $\operatorname{ETR}(1 \mathrm{yr}) *$ iFinancial & - & -0.212 & $-2.921 * * *$ & & & & \\
\hline $\operatorname{ETR}(1 \mathrm{yr}) * \mathrm{iLaw}$ & - & 0.123 & 0.741 & & & & \\
\hline $\operatorname{ETR}(3 y r)$ & - & & & -0.016 & -0.746 & & \\
\hline $\operatorname{ETR}(3 y r) *$ iFinancial & - & & & -0.234 & $-2.310 * *$ & & \\
\hline $\operatorname{ETR}(3 y r) * \mathrm{iLaw}$ & - & & & 0.125 & 0.484 & & \\
\hline $\operatorname{ETR}(5 y r)$ & - & & & & & -0.015 & -0.603 \\
\hline $\operatorname{ETR}(5 y r) \times$ iFinancial & - & & & & & -0.109 & -1.067 \\
\hline $\operatorname{ETR}(5 y r) x$ iLaw & - & & & & & -0.015 & -0.036 \\
\hline iFinancial & $?$ & 0.179 & $3.096^{* * *}$ & 0.205 & $2.625 * * *$ & 0.099 & 1.283 \\
\hline iLaw & $?$ & -0.126 & -1.001 & -0.106 & -0.543 & 0.022 & 0.072 \\
\hline OI & - & -0.383 & $-7.750 * * *$ & -0.261 & $-4.969 * * *$ & -0.132 & $-2.120 * *$ \\
\hline MB & + & 0.027 & $23.430 * * *$ & 0.029 & $23.211 * * *$ & 0.029 & $19.415^{* * *}$ \\
\hline $\operatorname{LnA}$ & + & 0.036 & $19.873 * * *$ & 0.034 & $18.041 * * *$ & 0.036 & $15.144 * * *$ \\
\hline DEP & - & -0.853 & $-4.373 * * *$ & -0.973 & $-4.473 * * *$ & -1.027 & $-3.955 * * *$ \\
\hline FA & + & 0.175 & $6.742 * * *$ & 0.176 & $6.089 * * *$ & 0.146 & $4.249 * * *$ \\
\hline RND & $?$ & -0.035 & $-1.787^{*}$ & -0.015 & $-2.559 * *$ & -0.013 & -1.085 \\
\hline DIV & - & -0.595 & $-3.966 * * *$ & -0.657 & $-4.220 * * *$ & -0.700 & $-3.726 * * *$ \\
\hline $\mathrm{AZ}$ & - & -0.016 & $-22.278 * * *$ & -0.018 & $-19.639 * * *$ & -0.019 & $-15.461 * * *$ \\
\hline Constant & $?$ & 0.003 & 0.067 & -0.009 & -0.203 & -0.108 & $-2.269 * *$ \\
\hline Year Effects & $?$ & Yes & & Yes & & Yes & \\
\hline Industry Effects & $?$ & Yes & & Yes & & Yes & \\
\hline Observations & & 3,264 & & 2,750 & & 1,959 & \\
\hline Adj. $\mathrm{R}^{2}$ & & 0.540 & & 0.545 & & 0.548 & \\
\hline
\end{tabular}

$\underline{\text { Panel B: Inside directors (H2b) }}$

\begin{tabular}{|c|c|c|c|c|c|c|c|}
\hline Variable & Pred. Sign & Coef. & $t$-stat. & Coef. & $t$-stat. & Coef. & $t$-stat. \\
\hline ETR(1yr) & - & -0.017 & -1.041 & & & & \\
\hline $\operatorname{ETR}(1 \mathrm{yr}) *$ dFinancial & - & -0.105 & -1.141 & & & & \\
\hline $\operatorname{ETR}(1 \mathrm{yr}) * \mathrm{dLaw}$ & - & 0.012 & 0.043 & & & & \\
\hline $\operatorname{ETR}(3 y r)$ & - & & & -0.035 & $-1.685^{*}$ & & \\
\hline $\operatorname{ETR}(3 y r) *$ dFinancial & - & & & -0.057 & -0.447 & & \\
\hline
\end{tabular}




\begin{tabular}{|c|c|c|c|c|c|c|c|}
\hline $\operatorname{ETR}(3 y r) *$ dLaw & - & & & -0.540 & $-2.215^{* *}$ & & \\
\hline $\operatorname{ETR}(5 y r)$ & - & & & & & -0.041 & $-1.897 *$ \\
\hline $\operatorname{ETR}(5 \mathrm{yr}) * \mathrm{dFinancial}$ & - & & & & & 0.067 & 0.501 \\
\hline $\operatorname{ETR}(5 y r) * d L a w$ & - & & & & & -0.230 & -0.797 \\
\hline dFinancial & $?$ & 0.142 & $1.947 *$ & 0.109 & 1.114 & 0.029 & 0.286 \\
\hline dLaw & $?$ & 0.060 & 0.271 & 0.514 & $2.764 * * *$ & 0.337 & 1.582 \\
\hline OI & - & -0.375 & $-7.629 * * *$ & -0.254 & $-4.836 * * *$ & -0.135 & $-2.174 * *$ \\
\hline MB & + & 0.027 & $23.782 * * *$ & 0.029 & $23.620 * * *$ & 0.029 & $19.572 * * *$ \\
\hline $\operatorname{LnA}$ & + & 0.036 & $20.005 * * *$ & 0.034 & $17.997 * * *$ & 0.036 & $15.218 * * *$ \\
\hline DEP & - & -0.846 & $-4.341 * * *$ & -0.949 & $-4.354 * * *$ & -1.005 & $-3.741 * * *$ \\
\hline FA & + & 0.163 & $6.385 * * *$ & 0.160 & $5.582 * * *$ & 0.134 & $3.900 * * *$ \\
\hline RND & $?$ & -0.035 & $-1.809 *$ & -0.016 & $-2.701 * * *$ & -0.013 & -1.380 \\
\hline DIV & - & -0.583 & $-3.911 * * *$ & -0.619 & $-3.990 * * *$ & -0.648 & $-3.487 * * *$ \\
\hline $\mathrm{AZ}$ & - & -0.016 & $-22.287 * * *$ & -0.018 & $-19.635 * * *$ & -0.018 & $-15.577 * * *$ \\
\hline Constant & $?$ & 0.015 & 0.309 & -0.004 & -0.083 & -0.094 & $-2.009 * *$ \\
\hline Year Effects & $?$ & Yes & & Yes & & Yes & \\
\hline Industry Effects & $?$ & Yes & & Yes & & Yes & \\
\hline Observations & & 3264 & & 2750 & & 1959 & \\
\hline Adj. $\mathrm{R}^{2}$ & & 0.540 & & 0.548 & & 0.552 & \\
\hline
\end{tabular}

Standardized beta coefficients with robust $t$-statistics (Wooldridge, 2010) in the adjacent column. Variable definitions: All variables are defined in Table 2.

$* p<0.10, * * p<0.05, * * * p<0.010$. 
Table 9

Fama MacBeth (Newey) regression results - financial expertise of directors and corporate debt

Panel A: Outside directors (H1a)

\begin{tabular}{|c|c|c|c|c|c|c|c|}
\hline Variable & Pred. Sign & Coef. & $t$-stat. & Coef. & $t$-stat. & Coef. & $t$-stat. \\
\hline ETR(1yr) & - & -0.048 & $-2.083 *$ & & & & \\
\hline ETR(3yr) & - & & & -0.048 & $-2.666^{* *}$ & & \\
\hline $\operatorname{ETR}(5 y r)$ & - & & & & & 0.081 & 0.692 \\
\hline iFinancial & $?$ & -0.021 & -0.578 & 0.016 & 0.551 & 0.134 & 1.230 \\
\hline iLaw & $?$ & 0.051 & $1.780^{*}$ & 0.029 & 0.933 & 0.058 & 1.052 \\
\hline OI & - & -0.503 & $-3.236^{* * *}$ & -0.411 & $-2.376^{* *}$ & -0.278 & -1.805 \\
\hline MB & + & 0.028 & $13.808 * * *$ & 0.031 & $10.478 * * *$ & 0.031 & $10.106 * * *$ \\
\hline $\operatorname{LnA}$ & + & 0.026 & $2.858 * *$ & 0.031 & $9.099 * * *$ & 0.053 & $3.289 * * *$ \\
\hline DEP & - & -1.202 & $-5.180 * * *$ & -1.278 & $-3.878 * * *$ & -1.013 & $-3.637 * * *$ \\
\hline FA & + & 0.307 & $6.849 * * *$ & 0.234 & $4.320 * * *$ & 0.018 & 0.088 \\
\hline RND & $?$ & -0.423 & $-3.512 * * *$ & -0.345 & $-3.795 * * *$ & -0.645 & $-2.590 * *$ \\
\hline DIV & - & -0.705 & $-2.201 * *$ & -0.467 & $-2.555^{* *}$ & -0.326 & $-2.221^{*}$ \\
\hline $\mathrm{AZ}$ & - & -0.018 & $-14.388 * * *$ & -0.018 & $-13.657 * * *$ & -0.019 & $-8.972 * * *$ \\
\hline Constant & $?$ & -0.503 & $-3.236^{* * *}$ & -0.411 & $-2.376^{* *}$ & -0.278 & -1.805 \\
\hline Industry Effects & $?$ & Yes & & Yes & & Yes & \\
\hline Observations & & 3,264 & & 2,750 & & 1,959 & \\
\hline Adj. $\mathrm{R}^{2}$ & & 0.545 & 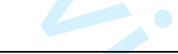 & 0.551 & & 0.556 & \\
\hline
\end{tabular}

Panel B: Inside directors (H1b)

\begin{tabular}{|c|c|c|c|c|c|c|c|}
\hline Variable & Pred. Sign & Coef. & $t$-stat. & Coef. & $t$-stat. & Coef. & $t$-stat. \\
\hline ETR(1yr) & - & -0.087 & -1.133 & & & & \\
\hline $\operatorname{ETR}(3 y r)$ & - & & & -0.044 & $-2.856^{* *}$ & & \\
\hline $\operatorname{ETR}(5 y r)$ & - & & & & & 0.029 & 0.363 \\
\hline dFinancial & $?$ & -0.026 & -0.337 & 0.047 & 1.007 & 0.150 & $2.328 * *$ \\
\hline dLaw & $?$ & -0.060 & -0.497 & 0.025 & 0.362 & 0.136 & $2.921 * *$ \\
\hline OI & - & -0.499 & $-3.067 * * *$ & -0.418 & $-2.277 * *$ & -0.268 & -1.662 \\
\hline $\mathrm{MB}$ & + & 0.027 & $8.888 * * *$ & 0.032 & $10.459 * * *$ & 0.034 & $9.576 * * *$ \\
\hline LnA & + & 0.013 & 0.585 & 0.032 & $10.680 * * *$ & 0.055 & $2.923 * *$ \\
\hline DEP & - & -1.076 & $-4.820 * * *$ & -1.331 & $-3.809^{* * *}$ & -0.964 & $-3.717 * * *$ \\
\hline FA & + & 0.261 & $9.327 * * *$ & 0.205 & $3.290 * * *$ & 0.091 & 0.760 \\
\hline RND & $?$ & 0.071 & 0.124 & -0.273 & $-2.263 * *$ & -0.666 & $-2.337 * *$ \\
\hline DIV & - & 0.176 & 0.223 & -0.418 & $-2.063^{*}$ & -0.278 & $-1.915^{*}$ \\
\hline $\mathrm{AZ}$ & - & -0.019 & $-11.844 * * *$ & -0.018 & $-13.990 * * *$ & -0.020 & $-10.703 * * *$ \\
\hline Constant & $?$ & 0.349 & 1.396 & 0.140 & $2.560 * *$ & -0.144 & -0.675 \\
\hline Industry Effects & $?$ & Yes & & Yes & & Yes & \\
\hline Observations & & 3264 & & 2750 & & 1959 & \\
\hline Adj. $\mathrm{R}^{2}$ & & 0.545 & & 0.551 & & 0.556 & \\
\hline
\end{tabular}

Standardized beta coefficients with robust $t$-statistics (Wooldridge, 2010) in the adjacent column. Variable definitions: All variables are defined in Table 2.

$* p<0.10, * * p<0.05, * * * p<0.010$. 
Table 10

Fama MacBeth (Newey) regression results - debt-substitution effect and outside/inside directors

Panel A: Outside directors (H2a)

\begin{tabular}{|c|c|c|c|c|c|c|c|}
\hline Variable & Pred. Sign & Coef. & $t$-stat. & Coef. & $t$-stat. & Coef. & $t$-stat. \\
\hline ETR(1yr) & - & -0.028 & $-2.418 * *$ & & & & \\
\hline $\operatorname{ETR}(1 \mathrm{yr}) *$ iFinancial & - & -0.212 & $-3.301 * * *$ & & & & \\
\hline $\operatorname{ETR}(1 \mathrm{yr}) * \mathrm{iLaw}$ & - & 0.123 & 0.729 & & & & \\
\hline $\operatorname{ETR}(3 y r)$ & - & & & -0.057 & $-4.209 * * *$ & & \\
\hline $\operatorname{ETR}(3 y r) *$ iFinancial & - & & & -0.234 & $-2.653 * * *$ & & \\
\hline $\operatorname{ETR}(3 y r) *$ iLaw & - & & & 0.125 & 0.501 & & \\
\hline $\operatorname{ETR}(5 y r)$ & - & & & & & $-0.036^{* *}$ & -2.462 \\
\hline $\operatorname{ETR}(5 y r) x$ iFinancial & - & & & & & -0.109 & -1.507 \\
\hline $\operatorname{ETR}(5 y r) \times$ iLaw & - & & & & & -0.015 & -0.045 \\
\hline iFinancial & $?$ & 0.018 & 1.114 & 0.033 & $1.933^{*}$ & 0.022 & 1.056 \\
\hline iLaw & $?$ & -0.032 & -0.753 & -0.015 & -0.313 & 0.011 & 0.203 \\
\hline OI & - & $-0.383 * * *$ & -7.746 & $-0.261 * * *$ & -5.250 & $-0.132 * *$ & -2.264 \\
\hline MB & + & $0.027 * * *$ & 27.494 & $0.029 * * *$ & 25.598 & $0.029 * * *$ & 21.830 \\
\hline $\operatorname{LnA}$ & + & $0.036^{* * *}$ & 19.977 & $0.034 * * *$ & 17.787 & $0.036^{* * *}$ & 15.516 \\
\hline DEP & - & $-0.853 * * *$ & -4.765 & $-0.973 * * *$ & -4.842 & $-1.027 * * *$ & -4.267 \\
\hline FA & + & $0.175^{* * *}$ & 7.275 & $0.176^{* * *}$ & 6.664 & $0.146^{* * *}$ & 4.761 \\
\hline RND & $?$ & $-0.035^{* * *}$ & -3.421 & $-0.015 * *$ & -2.073 & -0.013 & -1.119 \\
\hline DIV & - & $-0.595 * * *$ & -3.871 & $-0.657 * * *$ & -4.260 & $-0.700 * * *$ & -3.934 \\
\hline $\mathrm{AZ}$ & - & $-0.016^{* * *}$ & -28.611 & $-0.018 * * *$ & -27.288 & $-0.019 * * *$ & -22.201 \\
\hline Constant & $?$ & 0.031 & 0.552 & 0.021 & 0.349 & -0.093 & -1.477 \\
\hline Industry Effects & $?$ & Yes & & Yes & & Yes & \\
\hline Observations & & 3,264 & & 2,750 & & 1,959 & \\
\hline Adj. $\mathrm{R}^{2}$ & & 0.545 & & 0.551 & & 0.556 & \\
\hline
\end{tabular}

Panel B: Inside directors (H2b)

\begin{tabular}{|c|c|c|c|c|c|c|c|}
\hline Variable & Pred. Sign & Coef. & $t$-stat. & Coef. & $t$-stat. & Coef. & $t$-stat. \\
\hline $\operatorname{ETR}(1 \mathrm{yr})$ & - & -0.028 & $-2.393 * *$ & & & & \\
\hline $\operatorname{ETR}(1 \mathrm{yr}) *$ dFinancial & - & -0.105 & -1.242 & & & & \\
\hline $\operatorname{ETR}(1 \mathrm{yr}) * \mathrm{dLaw}$ & - & 0.012 & 0.052 & & & & \\
\hline $\operatorname{ETR}(3 y r)$ & - & & & -0.050 & $-3.688 * * *$ & & \\
\hline $\operatorname{ETR}(3 y r) *$ dFinancial & - & & & -0.057 & -0.649 & & \\
\hline $\operatorname{ETR}(3 y r) *$ dLaw & - & & & -0.54 & $-2.703 * * *$ & & \\
\hline $\operatorname{ETR}(5 y r)$ & - & & & & & -0.038 & $-2.694 * * *$ \\
\hline $\operatorname{ETR}(5 y r) *$ dFinancial & - & & & & & 0.067 & 0.663 \\
\hline $\operatorname{ETR}(5 y r) * d L a w$ & - & & & & & -0.23 & -0.819 \\
\hline dFinancial & $?$ & -0.375 & $-7.632 * * *$ & -0.254 & $-5.142 * * *$ & -0.135 & $-2.331 * *$ \\
\hline dLaw & $?$ & 0.027 & $27.727 * * *$ & 0.029 & $25.990 * * *$ & 0.029 & $22.133 * * *$ \\
\hline OI & - & -0.375 & $-7.632 * * *$ & -0.254 & $-5.142 * * *$ & -0.135 & $-2.331 * *$ \\
\hline MB & + & 0.027 & $27.727 * * *$ & 0.029 & $25.990 * * *$ & 0.029 & $22.133 * * *$ \\
\hline $\operatorname{LnA}$ & + & 0.036 & $19.952 * * *$ & 0.034 & $17.811 * * *$ & 0.036 & $15.631 * * *$ \\
\hline
\end{tabular}




\begin{tabular}{lccccccc} 
DEP & - & -0.846 & $-4.730 * * *$ & -0.949 & $-4.738 * * *$ & -1.005 & $-4.210^{* * *}$ \\
FA & + & 0.163 & $6.806 * * *$ & 0.160 & $6.080 * * *$ & 0.134 & $4.390^{* * *}$ \\
RND & $?$ & -0.035 & $-3.432 * * *$ & -0.016 & $-2.133 * *$ & -0.013 & -1.312 \\
DIV & - & -0.583 & $-3.797 * * *$ & -0.619 & $-4.021 * * *$ & -0.648 & $-3.659 * * *$ \\
AZ & - & -0.016 & $-28.526 * * *$ & -0.018 & $-27.240 * * *$ & -0.018 & $-22.080^{* * *}$ \\
Constant & $?$ & 0.022 & 0.393 & 0.007 & 0.121 & -0.096 & -1.528 \\
Industry Effects & $?$ & Yes & & Yes & & Yes \\
Observations & & 3264 & & 2750 & & 1959 \\
Adj. ${ }^{2}$ & & 0.545 & & 0.553 & & 0.56 \\
\hline
\end{tabular}

Standardized beta coefficients with robust $t$-statistics (Wooldridge, 2010) in the adjacent column. Variable definitions: All variables are defined in Table 2.

$* p<0.10, * * p<0.05, * * * p<0.010$. 